University of Tennessee Health Science Center UTHSC Digital Commons

\title{
The Effect of L-Proline on Two Recombinant AMPA Glutamate Receptors
}

Adetutu Abiose Oyelami

University of Tennessee Health Science Center

Follow this and additional works at: https://dc.uthsc.edu/dissertations

Part of the Medicine and Health Sciences Commons

\section{Recommended Citation}

Oyelami, Adetutu Abiose, "The Effect of L-Proline on Two Recombinant AMPA Glutamate Receptors" (2010). Theses and Dissertations (ETD). Paper 189. http://dx.doi.org/10.21007/etd.cghs.2010.0235.

This Thesis is brought to you for free and open access by the College of Graduate Health Sciences at UTHSC Digital Commons. It has been accepted for inclusion in Theses and Dissertations (ETD) by an authorized administrator of UTHSC Digital Commons. For more information, please contact jwelch30@uthsc.edu. 


\title{
The Effect of L-Proline on Two Recombinant AMPA Glutamate Receptors
}

\begin{abstract}
L-proline is a non-essential amino acid and one of the major amino acid constituents of extracellular fluid. Specific mutations in genes that control proline metabolism lead to hyperprolinemia which is characterized by an increase in the level of blood and cerebrospinal fluid concentration of I-proline. In fact, deletion or mutation of the PRODH gene which codes for proline oxidase (POX) / proline dehydrogenase which is critical for proline metabolism leads to Type I hyperprolinemia and is strongly associated with schizophrenia, autism and mental retardation. Proline has previously been shown to be a low affinity agonist at glutamate and glycine receptors. Because schizophrenia is thought to arise from glutamate receptor hypofunction and I-proline can act at glutamate receptors, it is necessary to understand whether increase in I-proline can contribute to glutamate receptor hypofunction.
\end{abstract}

The aim of this research was to determine the pharmacological profile of physiological and pathophysiological relevant concentrations of I-proline at two recombinant AMPA receptors: homomeric GluR1 and heteromeric GluR1/2. Dose response to I-proline (concentrations of $3 \mu \mathrm{M}-10 \mathrm{mM}$ ) at homomeric GluR1 and heteromeric GluR1/2 receptors were determined and compared to saturating concentration of glutamate $(10 \mathrm{mM})$. The effect of tonically present physiological $(3 \mu \mathrm{M})$ or pathophysiological $(30 \mu \mathrm{M})$ levels of I-proline on glutamate-evoked responses at both receptor types were also determined. This research supports previous findings that l-proline is a low affinity agonist at glutamate receptors activating less than $5 \%$ of current elicited by a saturating concentration of glutamate $(10 \mathrm{mM})$. Tonically present pathophysiological concentration of I-proline was observed to lead to a decrease in glutamate activation of homomeric GluR1 but not heteromeric GluR1/2 receptors. This decrease in glutamate-induced current was blocked by the application of $0.1 \mathrm{mM}$ cyclothiazide indicating that at pathophysiological concentrations I-proline leads to selective desensitization of GluR1 receptors. These actions of I-proline may be relevant for understanding how hyperprolinemia contributes to glutamate receptor hypofunction in schizophrenia.

\section{Document Type}

Thesis

\section{Degree Name}

Master of Science (MS)

\section{Program}

Biomedical Sciences

\section{Research Advisor}

Steven J. Tavalin, Ph.D.

\section{Keywords}

AMPA receptors, Glutamate receptors, Hyperprolinemia, L-Proline, Schizophrenia

\section{Subject Categories}

Medicine and Health Sciences 


\title{
THE EFFECT OF L-PROLINE ON TWO RECOMBINANT AMPA GLUTAMATE RECEPTORS
}

\author{
A Thesis \\ Presented for \\ The Graduate Studies Council \\ The University of Tennessee \\ Health Science Center \\ In Partial Fulfillment \\ Of the Requirements for the Degree \\ Master of Science \\ From The University of Tennessee
}

By

Adetutu Abiose Oyelami

May 2010 
Copyright (C) 2010 by Adetutu Abiose Oyelami

All rights reserved 


\section{DEDICATION}

This thesis is dedicated to my mum, Mrs. O. S. Oyelami and to memories of my dad. 


\section{ACKNOWLEDGEMENTS}

My gratitude to my research advisor, Dr. Steven Tavalin, for the guidance he gave during the process of working on my thesis. I also thank to my committee members Dr. Matt Ennis and Dr. Alex Dopico, as well as Dr. Pat Ryan and Dr. Ian Brooks for all the support and words of encouragement. 


\begin{abstract}
L-proline is a non-essential amino acid and one of the major amino acid constituents of extracellular fluid. Specific mutations in genes that control proline metabolism lead to hyperprolinemia which is characterized by an increase in the level of blood and cerebrospinal fluid concentration of 1-proline. In fact, deletion or mutation of the PRODH gene which codes for proline oxidase (POX) / proline dehydrogenase which is critical for proline metabolism leads to type I hyperprolinemia and is strongly associated with schizophrenia, autism and mental retardation. Proline has previously been shown to be a low affinity agonist at glutamate and glycine receptors. Because schizophrenia is thought to arise from glutamate receptor hypofunction and 1-proline can act at glutamate receptors, it is necessary to understand whether increase in 1-proline can contribute to glutamate receptor hypofunction.

The aim of this research was to determine the pharmacological profile of physiological and pathophysiological relevant concentrations of 1-proline at two recombinant AMPA receptors: homomeric GluR1 and heteromeric GluR1/2. Dose response to 1-proline (concentrations of $3 \mu \mathrm{M}-10 \mathrm{mM}$ ) at homomeric GluR1 and heteromeric GluR1/2 receptors were determined and compared to saturating concentration of glutamate $(10 \mathrm{mM})$. The effect of tonically present physiological $(3 \mu \mathrm{M})$ or pathophysiological $(30 \mu \mathrm{M})$ levels of 1-proline on glutamate-evoked responses at both receptor types were also determined. This research supports previous findings that $1-$ proline is a low affinity agonist at glutamate receptors activating less than $5 \%$ of current elicited by a saturating concentration of glutamate $(10 \mathrm{mM})$. Tonically present pathophysiological concentration of 1-proline was observed to lead to a decrease in glutamate activation of homomeric GluR1 but not heteromeric GluR1/2 receptors. This decrease in glutamate-induced current was blocked by the application of $0.1 \mathrm{mM}$ cyclothiazide indicating that at pathophysiological concentrations 1-proline leads to selective desensitization of GluR1 receptors. These actions of 1-proline may be relevant for understanding how hyperprolinemia contributes to glutamate receptor hypofunction in schizophrenia.
\end{abstract}




\section{TABLE OF CONTENTS}

CHAPTER 1. INTRODUCTION ............................................................................1

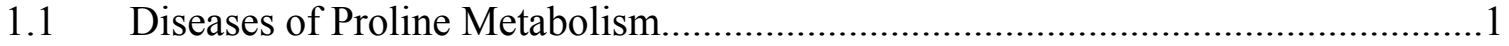

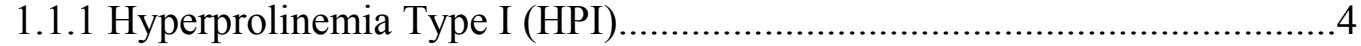

1.1.2 Hyperprolinemia Type II (HPII) ............................................................4

1.2 Pathophysiology of L-Proline ........................................................................

1.3 Glutamate Receptors: Physiological and Pathological Importance ........................5

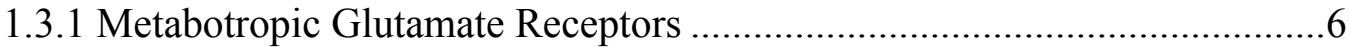

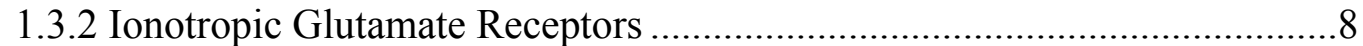

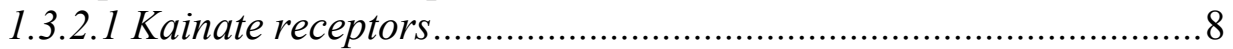

1.3.2.2 NMDA receptors ...................................................................

1.3.2.3 AMPA receptors.............................................................. 10

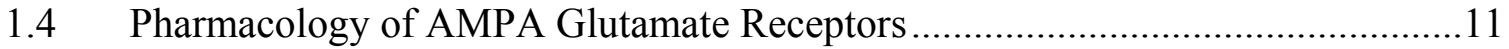

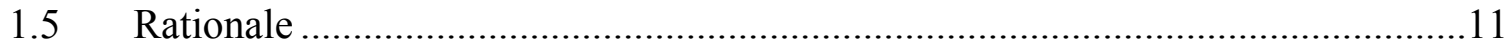

CHAPTER 2. MATERIALS AND METHODS..................................................13

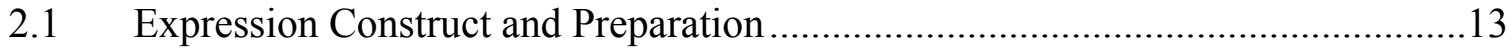

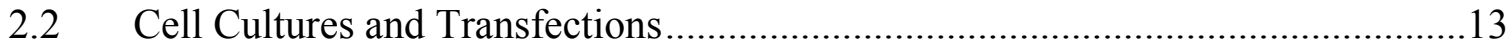

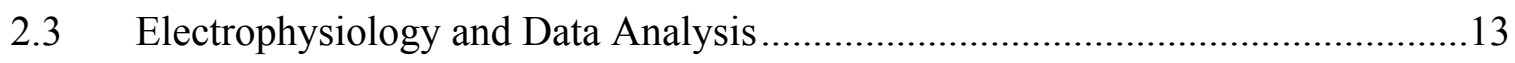

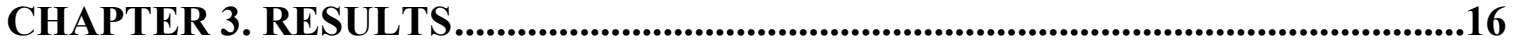

3.1 L-Proline is a Low Affinity Agonist at Recombinant AMPA Receptors .............16

3.2 The Effect of Tonic L-Proline Concentrations on Recombinant AMPA

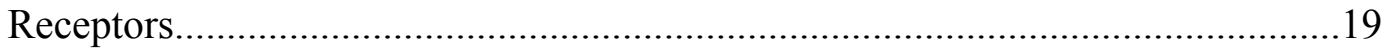

3.3 CTZ Application Blocks the Effect of Tonic L-Proline on GluR1 Currents .........19

3.4 Effect of Pathophysiological L-Proline Concentration on Paired-Pulse-Ratio

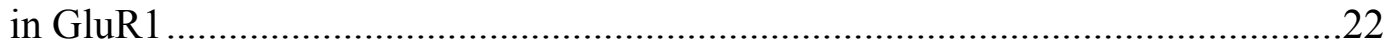

CHAPTER 4. DISCUSSION .............................................................................................25

4.1 L-Proline as a Partial Agonist at Recombinant AMPA Receptor........................25

4.2 L-Proline Disruption of Glutamate-Induced Current at Recombinant

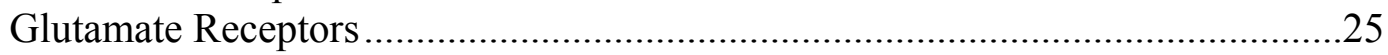

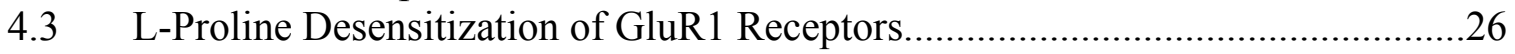

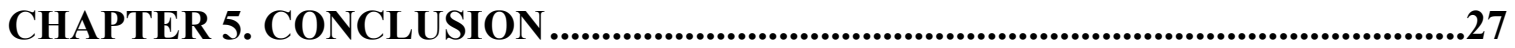

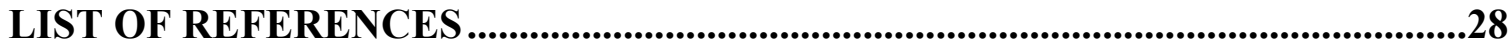

VITA 


\section{LIST OF FIGURES}

Figure 1-1 Metabolic Pathway of Proline and Related Amino Acids .........................2

Figure 1-2 Classification of Glutamate Receptors...............................................

Figure 1-3 Structure of AMPA Receptor Subunit .............................................

Figure 2-1 Current-Voltage Relationship for GluR1 and GluR1/2 Transfected Cells ................................................................................15

Figure 3-1 L-Proline Dose Response for GluR1 and GluR1/2 ...............................17

Figure 3-2 Current Density of GluR1 and GluR1/2 ............................................18

Figure 3-3 The Effect of Tonic L-Proline Levels on GluR1 Currents ......................20

Figure 3-4 The Effect of Tonic L-Proline Levels on GluR1/2 Currents .....................21

Figure 3-5 CTZ Application Blocks the Effect of Tonic L-Proline on GluR1

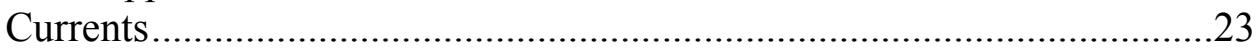

Figure 3-6 Effect of Pathophysiological L-Proline Concentration on PairedPulse-Ratio in GluR1 .24 


\section{CHAPTER 1. INTRODUCTION}

Proline is classified as a non-essential amino acid in adults and full-term infants (Miller et al. 1995; Phang et al. 2001). It can be derived from glutamine in the liver, small intestine and the kidney (Bertolo and Burrin 2008). L-proline is one of the major amino acid constituent of extracellular fluid with a plasma concentration of $37-312 \mu \mathrm{M}$ (Phang et al. 2001; Afenjar et al. 2007). The concentration of proline in the cerebrospinal fluid (CSF) is about a $1 \%$ of the serum concentration and ranges from 1-4 $\mu \mathrm{M}$ (Phang et al. 2001). Proline, like other known neurotransmitters in the central nervous system (CNS), is maintained in homeostasis by the activity of high affinity proline transporters. Thus suggesting that proline itself is a neurotransmitter (Renick et al. 1999; Phang et al. 2001).

Proline can be derived from glutamate or ornithine through the common precursors pyrroline-5-carboxylate (P5C) or glutamic- $\gamma$-semialdehyde (Phang et al. 2001). The conversion of glutamate and glutamine into the intermediate $\mathrm{P} 5 \mathrm{C}$ is catalyzed by the enzyme P5C synthase (Figure 1-1) (Bertolo and Burrin 2008). This step which is central to the synthesis/metabolism of proline is restricted to the gut (Jones 1985; Bertolo and Burrin 2008). Mutation of enzymes in the metabolic pathways controlling the synthesis (anabolism) as well as the breakdown (catabolism) of proline, results in disease conditions which include hyperprolinemia (Phang et al. 2001).

\subsection{Diseases of Proline Metabolism}

The conditions resulting from alteration in the metabolism of proline include hyperprolinemia type I (HPI), hyperprolinemia type II (HPII), ornithine aminotransferase (OAT) deficiency, hydroxyprolinemia, iminoglycinuria and $\Delta$-1-pyrroline-5-carboxylic acid (P5C) synthetase deficiency (Table 1-1) (Phang et al. 2001; Mitsubuchi et al. 2008). Each of these conditions is caused by a mutation or deletion in one of the genes coding for proteins in the metabolic pathways of proline (Figure 1-1) (Bertolo and Burrin 2008; Mitsubishi et al. 2008). Only three of these conditions, HPI, HPII and P5C synthase deficiency, however result in changes in plasma and CSF concentration of proline (Phang et al. 2001).

Disruption of proline catabolism which results in an increase in proline concentration beyond the physiological range is known as hyperprolinemia (Woody et al. 1969; Afenjar et al. 2007). Hyperprolinemia is an autosomal ressessive condition caused by mutations in genes that code for one of two enzymes: proline oxidase (POX) / proline dehydrogenase (PRODH) and $\Delta$ - 1-pyrroline-5-carboxylic dehydrogenase (P5CDH) (Woody et al. 1969; Phang et al. 2001). In hyperprolinemia, a 10-fold increase plasma proline concentration is accompanied by an equivalent 10-fold increase in the CSF (Phang et al. 2001). Hyperprolinemia has been associated with schizophrenia, 


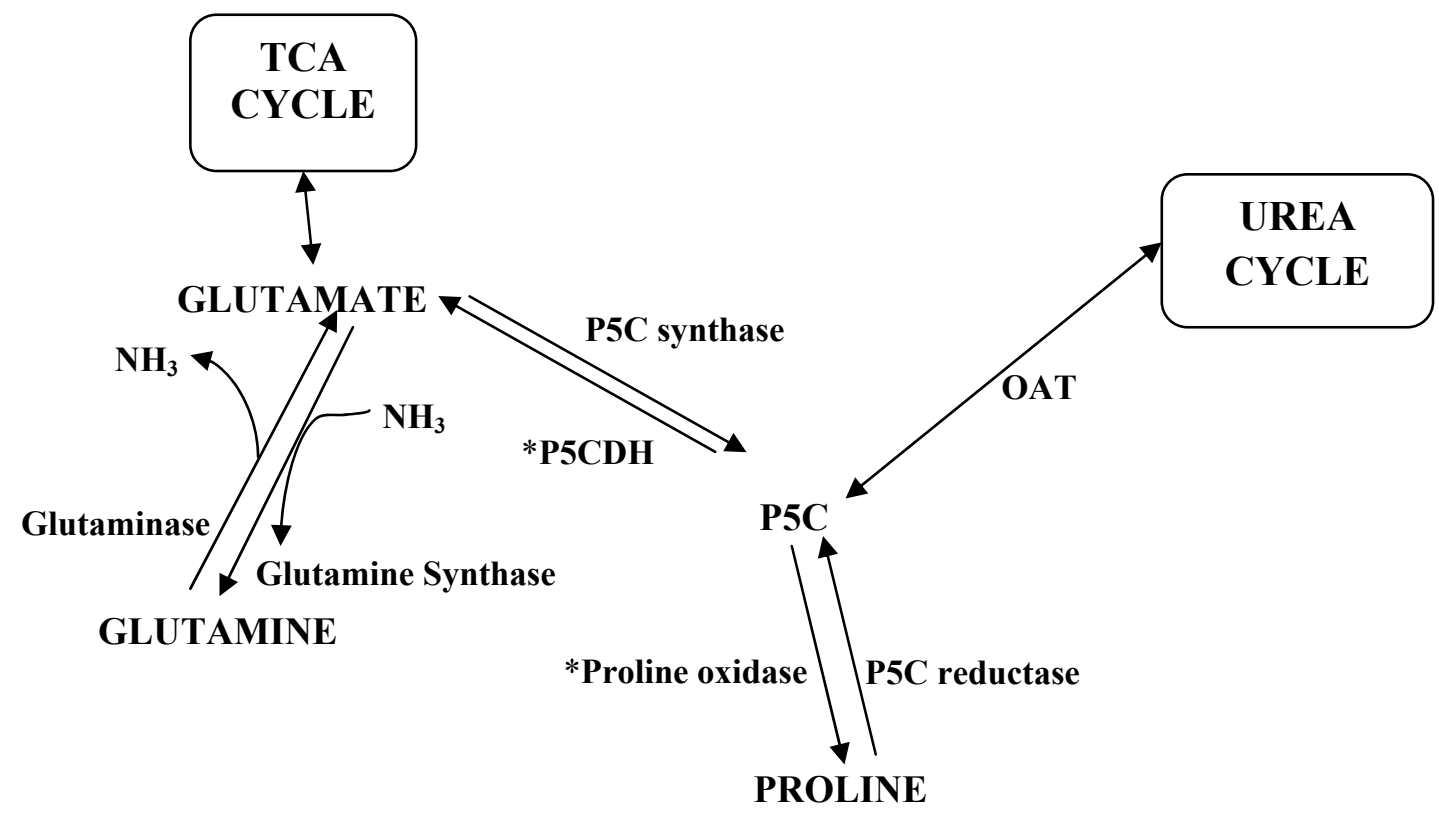

Figure 1-1 Metabolic Pathway of Proline and Related Amino Acids

Hyperprolinemia type I is caused by a mutation or deletion of the PRODH gene which codes for the enzyme proline oxidase that catalyses the conversion of proline to $\Delta-1$ proline-5-carboxylate. Hyperprolinemia type II is caused by a mutation of deletion in the $\Delta$-1-proline-5-carboxylate acid dehydrogenase (P5CDH). Reprinted with permission from Bertolo RF, Burrin DG (2008). Comparative aspects of tissue glutamine and proline metabolism. J Nutr 138:2032S-2039S. 
Table 1-1 Characteristics of human enzymes involved in proline metabolism and associated diseases

\begin{tabular}{llllll}
\hline & P5C synthase & OAT & POX & P5C dehydrogenase & Prolidase \\
\hline EC & None & EC26.1.13 & None & EC1.5.1.12 & EC3.4.13.9 \\
$\begin{array}{l}\text { Subcellular } \\
\text { location }\end{array}$ & $\begin{array}{l}\text { Mitochondria } \\
\text { inner membrane }\end{array}$ & $\begin{array}{l}\text { Mitochondrial } \\
\text { matrix }\end{array}$ & $\begin{array}{l}\text { Mitochondrial } \\
\text { inner membrane }\end{array}$ & $\begin{array}{l}\text { Mitochondrial } \\
\text { matrix }\end{array}$ & Cytoplasm \\
$\begin{array}{l}\text { Disease } \\
\text { association }\end{array}$ & Hypoprolinemia & Gyrate atrophy & HPI & HPII & $\begin{array}{l}\text { Prolidase } \\
\text { deficiency }\end{array}$ \\
& Hypocitrullinemia & & & & $19 \mathrm{q} 12-13.11$ \\
& Hypoornithinemia & & & & \\
& Hyperammonemia & & $22 \mathrm{q} 11.2$ & 1p36 & \\
\hline
\end{tabular}

Mutations in the enzymes P5C synthase, POX and P5C dehydrogenase lead to disruption in plasma proline concentration. Reprinted with permission from Mitsubuchi H, Nakamura K, Matsumoto S, Endo F (2008). Inborn errors of proline metabolism. J Nutr 138:2016S-2020S. 
autism, epilepsy as well as neuronal disorders which include mental retardation, epilepsy and delays in psychomotor development, as well as aggression in some patients (Flynn et al. 1989, Afenjar et al. 2007, Zinkstok et al. 2008). Thus, it is important to understand the actions of proline, particularly within the CNS.

There are two different types of hyperprolinemia: Hyperprolinemia Type I (HPI) and Hyperprolinemia Type II (HPII). Although HPI and HPII result in elevation of proline levels, there are differences in the magnitude of proline elevation as well as in the mutations that cause these disorders (Valle et al. 1976; Phang et al. 2001; Jacquet et al. 2002).

\subsubsection{Hyperprolinemia Type I (HPI)}

HPI is characterized by a 5-10 fold increase in the normal concentration of plasma proline (Phang et al. 2001; Jacquet et al. 2002). The increase in plasma proline level in HPI is due to a deletion or mutation in the proline dehydrogenase (PRODH) gene (Jacquet et al. 2002; Bender et al. 2005; Jacquet et al. 2005). The PRODH gene lies on the $\mathrm{q}$ arm of chromosome 22 at band 11.2 of the human genome. It encodes for the enzyme proline oxidase, an inner membrane mitochondria protein, which catalyzes the first step in the catabolism of proline to glutamate (Figure 1-1) (Campbell et al. 1997; Jacquet et al. 2002; Jacquet et al. 2005).

22q11.2 deletion syndrome (22q11.2DS) also known as DiGeorge syndrome (DGS) or Velo-cardio-facial syndrome (VCFS) is associated with increases in plasma proline levels of individuals, higher risk for schizophrenia, as well as high prevalence of autism spectrum disorder (Murphy et al. 1999, Goodman et al. 2000). The syndrome, as the name suggests, is caused by a micro deletion of chromosome 22q11.2. Symptoms of 22q11.2DS include congenital heart defects, seizures, palatal abnormalities, learning difficulties, hearing loss and in some case renal dysfunction (Shprintzen et al. 1978, Lipson et al. 1991, Humbertclaude et al. 2001). The cardiac defects associated with the syndrome appear to be generated primarily through the loss of the TBX1 gene, on chromosome 22q11.2 (Yagi et al. 2003). Neuropsychiatic symptoms associated with HPI include mental retardation, epilepsy and cognitive impairment (Di Rosa et al. 2008). This suggests that elevations in brain proline levels may contribute to the psychiatric disturbances observed in patients with 22q11.2DS.

\subsubsection{Hyperprolinemia Type II (HPII)}

HPII is characterized by typically higher elevations in proline concentration than in HPI. Proline levels are elevated 10 -15 fold in severe HPII with plasma concentrations as high as 413-1883 $\mu \mathrm{M}$ (Phang et al. 2001; Afenjar et al. 2007). The increase in proline in HPII is accompanied by an increase in the concentration of P5C, a by-product of proline degradation (Valle et al. 1976). HPII is due to a mutation or deletion in the 
ALDH4A1 gene which codes for the enzyme P5CDH. P5CDH catalyzes the breakdown of P5C to the amino acid glutamate (Phang et al. 2001).

\subsection{Pathophysiology of L-Proline}

In rats, acute systemic administration of 1-proline causes oxidative stress by reducing cytochrome c oxidase activity (Delwing et al. 2003; Delwing et al. 2007). When applied chronically l-proline has also been shown to lead to a decrease in membrane lipid content in the cerebellum of rats (Vianna et al. 2008), decrease in creatine kinase activity (Kessler et al. 2003), as well as decrease in the activities of $\mathrm{Na}^{+}-\mathrm{K}^{+}$-ATPase and acetycholinersterase (Pontes et al. 2001). The fact that 1-proline administration leads to a deficit in learning and memory suggest that increase in 1-proline levels affect the CNS (Davis et al, 1987).

High affinity $\mathrm{Na}^{+}$-and $\mathrm{Cl}^{-}$-dependent proline transporters (PROT) are widely expressed within a subset of glutamate neurons in the CNS (Hauptmann et al. 1983; Velaz-Faircloth et al. 1995). This structural localization of proline transporter, as well as studies showing that 1-proline affects excitatory synaptic transmission suggest that 1proline plays a role in the glutamate transmission (Cohen and Nadler 1997; Renick et al. 1999). Direct evidence of proline activity at synapses include the ability of 1-proline to activate glutamate and glycine receptors at concentrations above $1 \mathrm{mM}$ (Henzi et al. 1992). However, this concentration far exceeds the physiological or pathophysiological relevant concentrations of 1-proline within the CNS (Henzi et al. 1992, Cohen and Nadler 1997; Phang et al. 2001). At physiological and pathophysiological concentrations 1proline potentiates field excitatory postsynaptic potential (fEPSP) in neuronal slices (Cohen and Nadler 1997). Due to the limited literature on the effects of 1-proline at glutamate and glycine receptors, the spectrum of the pharmacological actions of 1-proline towards glutamate receptors remains largely unknown. This study therefore focused on the effects of 1-proline on two recombinant glutamate receptors.

\subsection{Glutamate Receptors: Physiological and Pathological Importance}

Ligand-gated glutamate receptors mediate the majority of excitatory neuronal transmission in the central nervous system (Dingledine et al. 1999). The amino acid glutamate binds to and activates a broad class of receptors collectively known as glutamate receptors (GluR) (Dingledine et al. 1999). The excitatory neurotransmitter glutamate and its receptors have been shown to be important in physiological processes such as neuronal plasticity as well as learning and memory (Tsien et al. 1996; Riedel et al. 2003).

Neuronal plasticity, the ability of the brain to be modified by experiences, is a phenomenon underpinning learning and memory (Alkon et al. 1982; Antonov et al. 2003). Examples of processes mediated by changes in the properties of neurons include long-term potentiation (LTP) (Bliss and Lomo 1973). Induction and maintenance of LTP, 
a persistent increase in synaptic strength, is thought to be required for the formation of long term memories (Jones et al. 2001; Pastalkova et al. 2006; Whitlock et al. 2006).

Excessive glutamate in the synaptic cleft leads to over-excitation of neurons, often leading to neuronal death due to excitotoxicity (Tanaka et al. 1996). Specific transporters maintain glutamate homeostasis by clearing excessive glutamate at synaptic cleft thereby shaping glutamate transmission (Diamond 2001; Katagiri et al. 2001; Hires et al. 2008). Glutamate-induced excitotoxicity is though to be mediated in part by the increase in intracellular $\mathrm{Ca}^{2+}$ concentration due to influx mediated by glutamate receptors (Schlaepfer and Bunge 1973, Tymianski et al. 1993). Many neurodegenerative disorders, such as Parkinson's, epilepsy Alzheimer's and Huntington's diseases have been attributed to glutamate-induced excitotoxicity (Tanaka 1996; Cha et al. 1998; Ozawa 1999).

Alteration in the composition, number, subtypes and/or activity of glutamate receptors have also been shown to be associated with mental illnesses, neurodegenerative diseases such as Alzheimer's and in other neurological disorders, such as epilepsy and ischemia (Meldrum 2000; Bernareggi et al. 2006; Borbely et al. 2009). Glutamate receptors are divided into two major groups based on the pathway that is activated upon binding of glutamate or other agonists to the receptors (Dingledine et al. 1999). The two major groups of glutamate receptors are metabotropic and ionotropic receptors as illustrated in Figure 1-2 (Kew and Kemp 2005).

\subsubsection{Metabotropic Glutamate Receptors}

The metabotropic glutamate receptor family (mGluR) currently consists of eight different subunits and genes and is divided into three different groups based on pharmacology, as well as the second messenger activated downstream to the receptors (Figure 1-1) (Dingledine et al. 1999). The activation of Group I mGluR family results in activation of second messenger signaling pathways such as phosphoinositol and results in an increase in cytoplasmic concentration of $\mathrm{Ca}^{2+}$ (Abe et al. 1992). mGluRs are coupled to G-proteins which can be inhibitory or excitatory (Dingledine et al. 1999, Kew and Kemp 2005).

Group I and Group II have been shown to be predominantly coupled to phospholipase C (PLC) signal, with the former activating and the latter inhibiting this pathway (Abe et al. 1992). Members of Group III mGluRs predominately inhibit $\mathrm{Ca}^{2+}$ channels and cyclic adenosine monophosphate (cAMP) generation (Okamoto et al. 1994). Members of the Group I receptors can also lead to the activation of intracellular signaling cascades which are independent of G-proteins and mediated by a src-tyrosine kinase (Heuss et al. 1999). 


\section{Glutamate receptor}

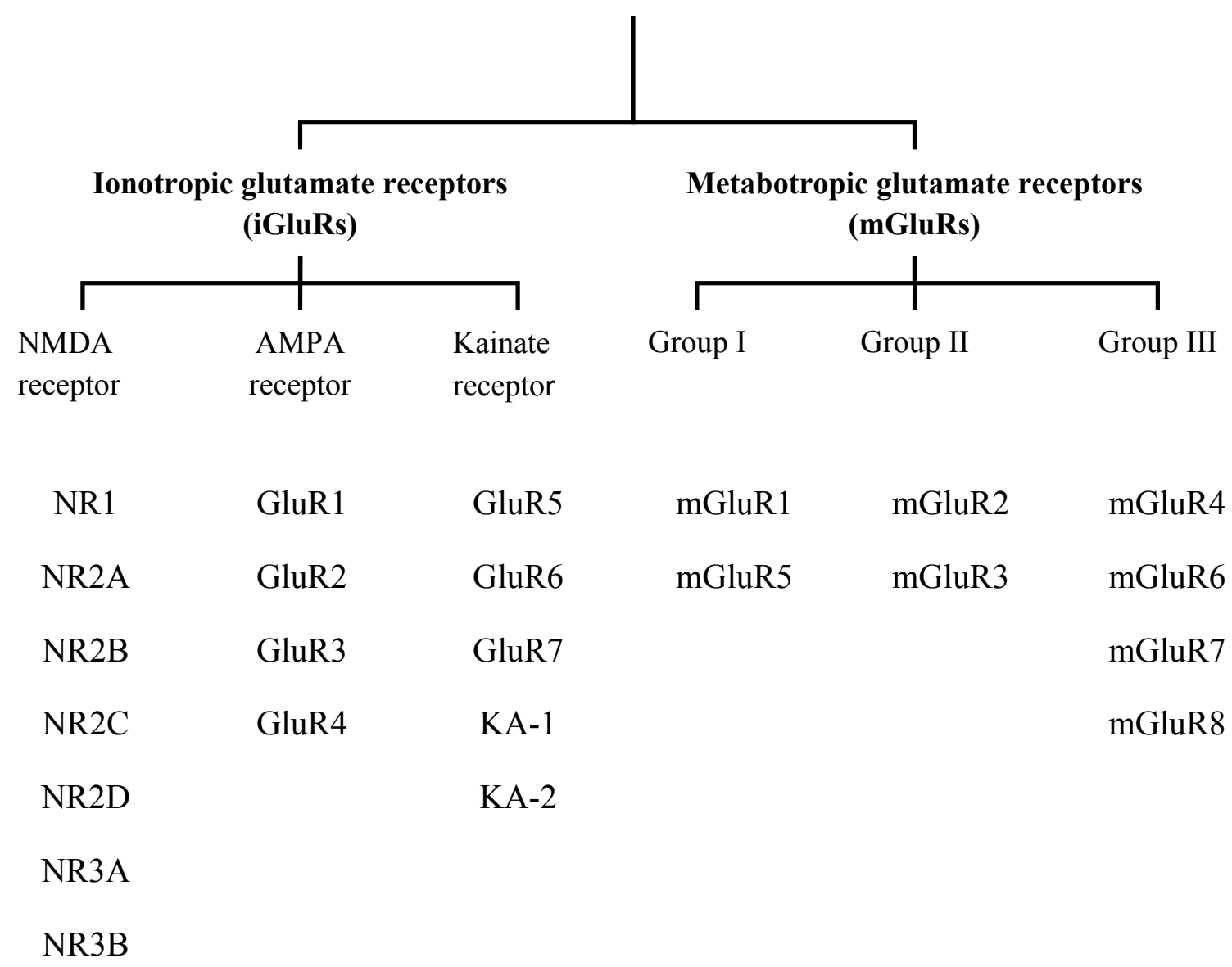

\section{Figure 1-2 Classification of Glutamate Receptors}

Glutamate receptor family, showing classification of ionotrophic and metabotropic glutamate receptors and subunits within each class. Reprinted with permission from Kew J, Kemp J (2005). Ionotropic and metabotropic glutamate receptor structure and pharmacology. Psychopharmacology 179:4-29. 


\subsubsection{Ionotropic Glutamate Receptors}

Ionotropic glutamate receptors (iGluRs) are ligand-gated ion channels concentrated in postsynaptic cells in clusters called postsynaptic densities (Petralia et al. 1994; Popratiloff et al. 1996). They are selectively permeable to $\mathrm{Na}^{+}, \mathrm{K}^{+}$and differentially permeable to $\mathrm{Ca}^{2+}$ (Burnashev et al. 1995). The ionotropic glutamate receptor is tetrameric. Based on the subunit composition a particular receptor is classified as homomeric or heteromeric. Each of the four subunits forming the receptors is a membrane protein with three transmembrane domains (M1, M3 and M4) with a reentrant loop (M2), an intracellular C-terminus and an extracellular Nterminus as shown in Figure 1-3 (Bennett and Dingledine 1995; Dingledine et al. 1999; Anand, 2000). The agonist binding site on each subunit is formed within two segments (S1 and S2) in two domains of the extracellular ligand binding core (Bennet and Dingledine 1995; Armstrong et al. 1998; Anand 2000; Naur et al. 2005). The binding of a ligand to iGluRs results in conformational changes and in the opening of the ion pore, allowing current to flow down its electrochemical gradient (Jin et al. 2003).

There are three major classes of ionotropic glutamate receptors: $\alpha$-amino-3hydroxy-5-methylisoxazole-4-propionic acid receptors (AMPAR), kainate receptors, and N-methyl-D-aspartate receptors (NMDAR) (Dingledine et al. 1999).

1.3.2.1 Kainate receptors: The kainate glutamate receptor family is formed by the glutamate receptor subunits GluR5-7, KA1 and KA2 (Dingledine et al. 1999). The proteins for all five subunits are encoded for by the genes GRIK1-5 respectively (Dingledine et al. 1999). KA1 and KA2 subunits show a higher affinity for kainate than all other subunits, however they do not result in the formation of functional homomeric receptors (Ren et al. 2003). Kainate receptors have been implicated in diseases such as early onset Huntington's, autism, schizophrenia and epilepsy (Jane et al. 2009).

1.3.2.2 NMDA receptors: Unique among the iGluRs, NMDA receptors require glycine as a coagonist as well as their ligand, glutamate, for activation (Wafford et al. 1995). NMDA receptors also have a voltage-dependent $\mathrm{Mg}^{2+}$ block which is absent in other classes of iGluRs and are permeable to $\mathrm{Ca}^{2+}$ (Mayer and Westrook 1987; Jahr and Stevens 1993). The current induced by activation of NMDA receptors has a longer duration than that induced by other types of ionotropic glutamate receptors due to prolonged opening time of the receptors and slower desensitization (Gibb and Colquhoun 1991). During desensitization the ligand remains bound to a receptor, however conformational changes in the receptor prevent the passage of current through the receptor. NMDA receptors unlike most ionotropic glutamate receptors are permeable to $\mathrm{Ca}^{2+}$ and therefore directly coupled to the build up of $\mathrm{Ca}^{2+}$ in the cytoplasm. Over activation of NMDA receptors therefore directly results in a $\mathrm{Ca}^{2+}$-dependent excitotoxicity (Alford et al. 1993; Christie and Jahr 2008). NMDA receptor-dependent $\mathrm{Ca}^{2+}$ permeability has been shown to be directly involved in the induction of LTP and in learning and memory through the activity of $\mathrm{Ca}^{2+} /$ calmodulin-dependent protein kinase II (CaMKII) (Sanhueza et al. 2007). 


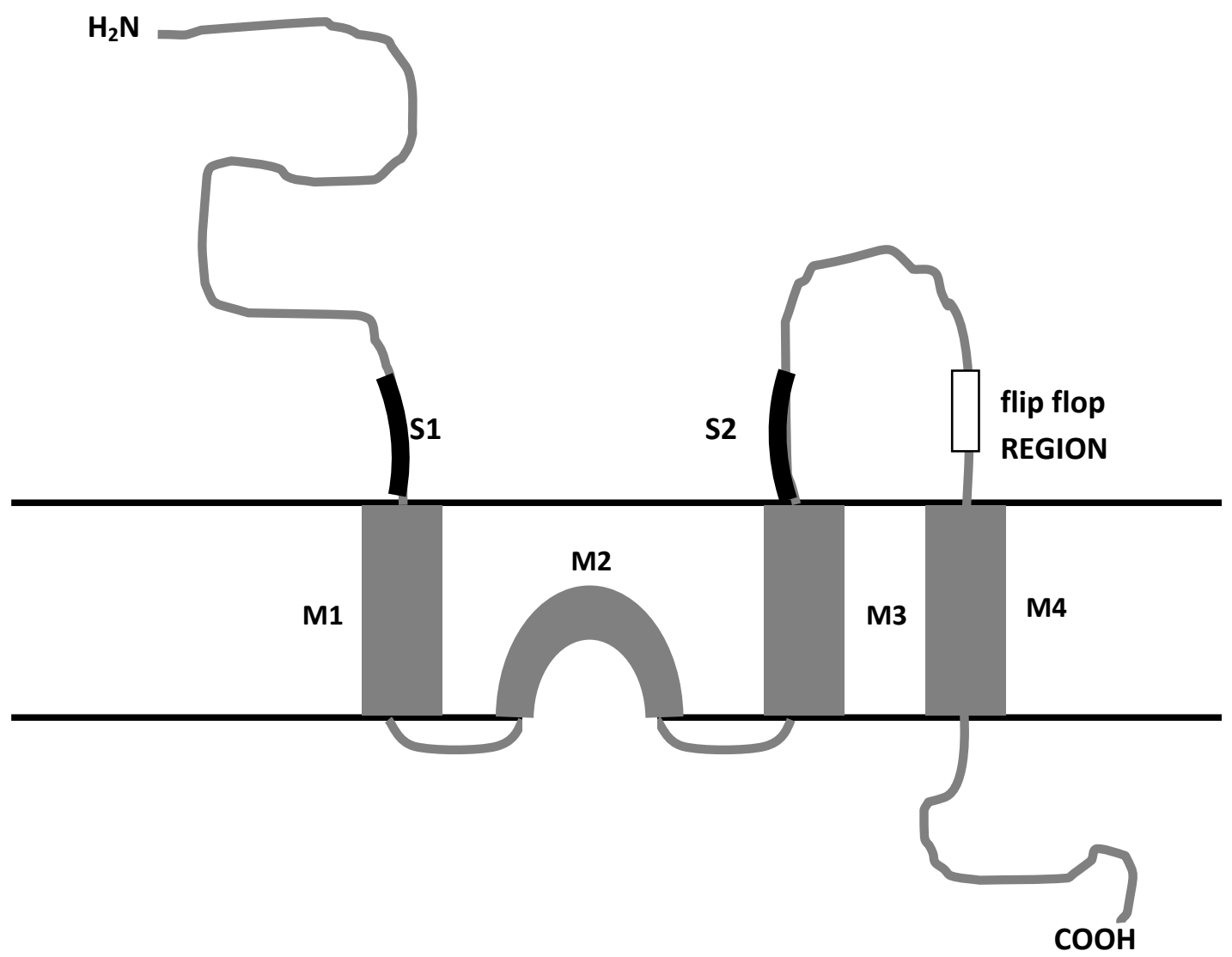

Figure 1-3 Structure of AMPA Receptor Subunit

Transmemebrane topology of a single subunit of the receptor showing the three transmembrane domains (M1, M3 and M4), re-entrant loop (M2), the ligand-binding domains (S1 and S2), the intracellular $\mathrm{C}$ terminal and an extracellular $\mathrm{N}$ terminal. Reprinted with permission from Dingledine R, Borges K, Bowie D, Traynelis S (1999). The glutamate receptor ion channels. Pharmacol Rev 51:7-62. 
1.3.2.3 AMPA receptors: AMPAR are tetrameric receptors composed of four subunits, GluR1-4 (Rosenmund et al. 1998 ). Each subunit can exist as a 'flip' or flop' which is a variant created by alternate splicing of a 115-base pair section of genes encoding the subunit. (Dingledine et al. 1999). Further posttranslational modifications can result in a great diversity of the receptors. Phosphorylation of amino acid residues on AMPA receptors by kinases such as protein kinase $\mathrm{A}$ (PKA), CaMKII and protein kinase $\mathrm{C}$ (PKC) provide a mechanism for controlling the activity of the receptors (Lee et al. 2003). The genes encoding the AMPA receptors are a single family including GRIA1, GRIA2, GRIA3 and GRIA4.

The different subunits can combine to form homomeric or heteromeric receptors which have different patterns of distribution within the brain. This suggests important differences in the properties of each subunit and the receptors they form (Wenthold et al. 1996; Mano and Teichiberg 1998). AMPA receptors are generally non-selective cation channels being permeable to $\mathrm{Na}^{+}$and $\mathrm{K}^{+}$and, in general, largely impermeable to $\mathrm{Ca}^{2+}$ ion in the CNS (Burnashev et al. 1995). $\mathrm{Ca}^{2+}$ permeability of AMPA receptors is largely dependent on the amino acid residue on position 586 of the GluR2 protein/subunit. This site is present at the conduction site in the pore formed by the subunits (Verdoon et al. 1991). GluR2 subunits undergo subunit-specific RNA editing resulting in the conversion of the encoded glutamine codon $(\mathrm{Q})$ to arginine $(\mathrm{R})$ that determines the kinetics of the channel (Lomeli et al. 1994). The unedited, GluR2-Q, subunit has relatively the same permeability to $\mathrm{Ca}^{2+}$ as other AMPA receptor subunits, and the edited GluR2-R have a reduced permeability to $\mathrm{Ca}^{2+}$ (Burnashev et al. 1996). AMPAR properties including rectification and $\mathrm{Ca}^{2+}$ permeability differ based on subunits composition. The edited GluR2-R subunit is impermeable to $\mathrm{Ca}^{2+}$, and co-expression of this subunit in a heteromeric receptor determines the $\mathrm{Ca}^{2+}$ permeability of the receptor (Burnashev et al. 1995; Geiger et al. 1995; Shi et al. 2001). GluR1 and GluR2 subunits of AMPA receptors are predominantly expressed in the hippocampus (Wenthold et al. 1996). There is a loss of both GluR1 and GluR2 subunit expression in the hippocampus in schizophrenia (Eastwood et al. 1995), therefore reductions in the activity of these receptors maybe important for the development of schizophrenia.

Glutamate receptor I (GluR1): Glutamate receptor I (GluR1) subunits can be expressed as homomers or heteromers with GluR2, GluR3 and/or GluR4 subunits (Boulter et al. 1990). Expression of GluR1 homomeric receptor varies throughout the CNS with preferential location in the cortex, striatum and spinal cord (Wenthold et al. 1996; Hermes et al. 2008; Lane et al. 2008). GluR1 is also necessary for the acquisition of short-term memory necessary, for acquisition of learning in a spatial memory task, as well as in the formation of LTP and LTD (Lee et al. 2003). Current generated by GluR1 homomers when expressed in human embryonic kidney (HEK) cell lines is mediated by the flow of $\mathrm{Na}^{+}, \mathrm{K}^{+}$and to a lesser extent $\mathrm{Ca}^{2+}$ (Dingledine et al. 1999). Homomeric GluR1 receptors are characterized by the ability to pass more current at a negative membrane potentials $(-60 \mathrm{mV})$ than at positive membrane potentials $(+60 \mathrm{mV})$ of the same magnitude, a property known as inward rectification (Burnashev et al. 1995). Homomeric GluR1 receptors are activated by agonists including AMPA, domoate, kainate and quisqualate (Dawson et al. 1990). 
GluR1/2: GluR1/2 heteromeric receptors are composed of both GluR1 and GluR2 subunits expressed as a tetramer, known as a dimer of dimers (Ayalon and Stern-bach 2001). GluR1/2 heteromers are the major receptor type within the hippocampus and increases in activity and numbers of both subunits are associated with manic-like behavior (Wenthold et al. 1996; Du et al. 2008). When expressed in mammalian cell lines the homomeric GluR1/2 exhibits a non-rectifying current-voltage (I-V) relationship and differ from the GluR1 homomers in their lower permeability to $\mathrm{Ca}^{2+}$. These differences in $\mathrm{I}-\mathrm{V}$ relationship can therefore be used as a means of differentiating between different receptors subtypes (Verdoorn et al. 1991; Burnashev et al. 1995).

\subsection{Pharmacology of AMPA Glutamate Receptors}

An agonist is any substance that binds to and activates a given receptor (Watkins 2000). It can be a naturally occurring substance, or a substance that binds with as high affinity to a receptor as its known naturally occurring agonist (Li et al. 1997). Agonist binding sites present on AMPA-type glutamate receptors have been mapped using molecular techniques to disrupt the agonist binding sites, as well as by the analysis of crystalline structures of bound molecule to receptors (Hogner et al. 2002). The AMPA agonist binding site has been mapped to amino acids within the $\mathrm{S} 1$ and $\mathrm{S} 2$ segments in both AMPA and kainate receptors ( $\mathrm{Li}$ et al. 1995; Hogner et al. 2002). Agonists can be broadly divided into either full or partial agonists. The classification of an agonist is based on the concentration of the agonist needed to elicit a response and the ability of that agonist to reach a concentration at which there is no further increase in the response generated from the receptor (Li et al. 1997; Traynor et al. 2001). Major known agonists at glutamate receptors include AMPA, NMDA and kainate.

A full agonist at a receptor is able to elicit a maximum affinity and/or efficacy at a receptor site, therefore producing a maximum response of the receptor or downstream to the activation of the receptor ( $\mathrm{Li}$ et al. 1997; Traynor et al. 2001). When compared to a full agonist, a partial agonist elicits sub-maximal response at the receptor site (Jin et al. 2003). It is therefore possible to classify agonists based on the electrophysiological response of the receptor subtype of interest (Yakushiji et al. 1989). Decrease in the current elicited by a partial agonist, at ionotropic glutamate receptors, is a result of a decrease in the receptor opening probability of the receptor (Jin et al. 2003; Maltsev et al. 2008; Kussius and Popescu 2009). The currents produced at NMDA receptors with the application of a partial agonist such as alanine has been shown to desensitize faster, there is however no evidence that a partial agonist is able to promote the entry of the receptor into a desensitized state (Kussius and Popescu 2009).

\subsection{Rationale}

Schizophrenia a chronic mental disorder with symptoms classified into three broad categories: positive symptoms, negative symptoms and cognitive symptoms (NIMH). Over the years two major molecular basis have been proposed for 
schizophrenia: glutamatergic hypofunction and dopaminergic hyperfunction (Mohn et al. 1999; Lang et al. 2007; Lisman et al. 2008). Glutamate hypofunction and in particular AMPA receptor hypofunction is backed by studies that have shown a disruption in AMPA receptor regulation is associated with schizophrenia. In particular a conditional knock-out of GluR1 receptors results in schizophrenic-like behavior in mice (Wiedholz et al. 2008). The association of 22q11.2DS and hyperprolinemia to schizophrenia point to a possible role of 1-proline in the pathology of schizophrenia (Jacquet et al. 2002; Jacquet et al. 2005). Hyperprolinemia has also been associated to other disease conditions such as autism and mental retardation (Afenjar et al. 2007; Shprintzen 2008).

Proline transporters have been shown to be highly expressed in glutamatergic pathways in the CNS (Hauptmann et al. 1983; Renick et al. 1999). This structural localization of proline transporter have led to the suggestion that 1-proline could play a role in the glutamate signal transmission pathways (Renick et al. 1999). Mutations in genes coding for enzymes in proline metabolism pathway results in conditions which include hyperprolinemia. Hyperprolinemia is also caused by errors in the catabolism of proline and is characterized by increases in the blood plasma levels of proline and its derivatives.

At concentrations greater than pathophysiologically relevant concentration in the CNS (1 mM) 1-proline has two opposite effects on membrane potential of rat dorsal horn neurons (Henzi et al. 1992). These effects, excitatory and inhibitory, are mediated by two different receptor types, the glutamate receptors and glycine receptors (Henzi et al. 1992; Phang et al. 2001). L-proline activates glycine receptors, NMDA receptors and nonNMDA glutamate receptors (Henzi et al. 1992; Phang et al. 2001). Inhibitory effects of proline is also mediated by the d-proline isomer-activation of glycine receptors (Henzi et al. 1992). In spite of the low agonist affinity of 1-proline for glutamate receptors, physiological $(3 \mu \mathrm{M})$ and pathophysiological $(30 \mu \mathrm{M})$ concentrations have been shown to potentiate glutamatergic transmission in the hippocampus (Cohen and Nadler 1997). Suggesting that even at very low concentrations 1-proline affects glutamate transmission.

These previous studies of the agonist activity of 1-proline were carried out in native receptors in neurons where currents recorded were pharmacologically dissected. Thus the identity and receptor composition contributing to proline-evoked responses are unclear. Given the physiological and pharmacological variation in the different glutamate receptors, there is a need to understand the spectrum of the agonist activity of proline at specific glutamate receptors.

Thus the aims of this study were:

1. To determine the effect of subunit composition on the sensitivity of recombinant AMPA receptors to 1-proline.

2. To determine if desensitization contributes to the sensitivity of AMPA receptors to l-proline.

3. To determine the effect of tonic 1-proline levels on glutamate activation of AMPA receptors as a model for hyperprolinemia. 


\section{CHAPTER 2. MATERIALS AND METHODS}

\subsection{Expression Construct and Preparation}

cDNA encoding for rat GluR1and GluR2 were in the pRK5 vector. pEGFP vector (Clontech) was used as a tranfection marker. Each construct was transformed into DH5 $\alpha$ cells and plated on Luria-Bertani (LB) agar plates supplemented with antibiotic to which the vectors had resistant genes. LB agar was supplemented with ampicillin $(50 \mu \mathrm{g} / \mathrm{ml})$ for propagation of GluR1 and GluR2 or kanamycin $(50 \mu \mathrm{g} / \mathrm{ml})$ for GFP. Plates were incubated at $37{ }^{\circ} \mathrm{C}$ overnight. A single colony was selected from each plate and grown in LB broth supplemented with ampicillin or kanamycin as noted above. The culture was allowed to grow overnight at $37^{\circ} \mathrm{C}$ in a shaking incubator at $300 \mathrm{rpm}$ for $16-18$ hours. The culture was harvested by centrifugation at $6000 \mathrm{rpm} 4{ }^{\circ} \mathrm{C}$ for 5 mins and plasmids were purified with the use of a Hi-speed maxi prep kit (Qiagen; Valencia, CA). UV absorbance $(260 \mathrm{~nm})$ was used to determine the concentration of the purified DNA. The plasmid DNA was stored at $-20{ }^{\circ} \mathrm{C}$ and later used for transfection into HEK 293 cells.

\subsection{Cell Cultures and Transfections}

Human embryonic kidney cells lines (HEK 293) were obtained from ATCC (CRL-1573, Manassas, VA). Only cells from passages 36-42 were used for experiments. The cells were grown in culture in media consisting of Dulbecco's Modified Eagle's Medium (DMEM) (Invitrogen; Carlsbad, CA), $10 \%$ fetal bovine serum (FBS) (Hyclone; Logan, UT) and penicillin $(100 \mathrm{U} / \mathrm{ml}) /$ streptomycin $(100 \mathrm{U} / \mathrm{ml})(\mathrm{P} / \mathrm{S})($ Invitrogen; Carlsbad, CA). Cells were maintained in an incubator with a temperature of $37^{\circ} \mathrm{C}$; with an air to $\mathrm{CO}_{2}$ ratio of 95:5\%. Cells were passaged every 4-5 days by trypsinization. The calcium phosphate precipitation technique was used for transfection of plasmids into HEK 293 cells (Chen and Okayama 1987). Transfection was performed using $1 \mu \mathrm{g}$ of each construct (GluR1 or GluR1 + GluR2). GFP $(0.2 \mu \mathrm{g})$ was included as a transfection marker. The cells were incubated after transfection at $37{ }^{\circ} \mathrm{C}$ and washed with phosphate buffered saline (PBS) (Invitrogen; Carlsbad, CA) 16-18 hours after transfection. The PBS was subsequently replaced with fresh media. Cells were returned to the incubator and electrophysiological recordings were performed 24 hours later.

\subsection{Electrophysiology and Data Analysis}

HEK cells for each experiment were selected by microscopic visualization of GFP epifluorescence. Whole-cell patch clamp recording were carried out using a Multiclamp 700A (Molecular devices; Union City, CA). Pipettes were fabricated from borosilicate glass (TW150F; WPI; Sarasota, FL) using a two-stage electrode puller (model PP830; Narshige; Tokyo, Japan). Only pipette with resistances of 2-4 M $\Omega$ were used. Pipettes were filled with intracellular solution containing $140 \mathrm{mM}$ cesium methanesulfonate, 10 $\mathrm{mM}$ HEPES, $5 \mathrm{mM}$ adenosine triphosphate (sodium salt), $5 \mathrm{mM} \mathrm{MgCl}, 2 \mathrm{mM} \mathrm{CaCl}_{2}$ and $10 \mathrm{mM}$ BAPTA at $\mathrm{pH}$ 7.40. The extracellular solution contained $150 \mathrm{mM} \mathrm{NaCl}, 5 \mathrm{mM}$ 
$\mathrm{KCl}, 1.8 \mathrm{mM} \mathrm{CaCl}_{2}, 1 \mathrm{mM} \mathrm{MgCl} 2,10 \mathrm{mM}$ HEPES and $10 \mathrm{mM}$ glucose with a $\mathrm{pH}$ of 7.40 and was perfused into the recording chamber at a flow rate of $1-2 \mathrm{ml} / \mathrm{min}$. Upon successful establishment of the whole-cell configuration, cells were lifted off the coverslip and positioned in the path of control flow line. Fast solution exchange was achieved by moving a series of flow pipes using a piezoelectric bimorph. Agonist-evoked currents were elicited every 10-30s. All experiments commenced by obtaining 5 consecutive stable currents in response to a saturating concentration of glutamate $(10 \mathrm{mM} ; 500 \mathrm{~ms})$.

To determine the 1-proline dose-response for recombinant AMPA receptors, 1proline $(3 \mu \mathrm{M}, 30 \mu \mathrm{M}, 300 \mu \mathrm{M}, 3 \mathrm{mM}$ or $10 \mathrm{mM})$ was applied for $500 \mathrm{~ms}$ with an interval of 10s between sweeps. Peak current evoked in response to l-proline at each concentration was normalized to the peak current obtained in response to glutamate. To assess the effect of tonic 1-proline concentrations on glutamate-evoked currents, 1-proline $(0 \mu \mathrm{M}, 3 \mu \mathrm{M}$ or $30 \mu \mathrm{M})$ was added to both control and glutamate $(10 \mathrm{mM})$ containing extracellular solution. Glutamate evoked current $(10 \mathrm{mM} ; 500 \mathrm{~ms})$ in the absence or presence of tonic 1-proline were elicited every 30s. Peak current each for sweep was normalized to the peak of the initial glutamate-evoked response. For paired-pulse experiments, a protocol was created to deliver two pulses of glutamate $(10 \mathrm{mM})$ in the tonic presence or absence of a pathophysiological relevant concentration of 1-proline (30 $\mu \mathrm{M})$. The pulses were delivered for $25 \mathrm{~ms}$ with a delay of $200 \mathrm{~ms}$ between the first and second pulses.

All currents were recorded at $-60 \mathrm{mV}$. For all cells used in data analysis, measured currents were normalized to the initial peak current. Currents were digitized at $5-10 \mathrm{kHz}$ and filtered at 1-2 kHz with a Digidata 1322A board and Clampex 9 software (Axon Instruments; Foster City, CA). Only cells with currents greater than $100 \mathrm{pA}$ induced by $10 \mathrm{mM}$ glutamate and membrane resistance $\geq 1.0 \mathrm{G} \Omega$ were included in the data analysis. I-V relationships were generated over the range $-60 \mathrm{mV}$ to $+40 \mathrm{mV}$, in 20 $\mathrm{mV}$ increments. I-V relationships were obtained at the onset of each experiment in order to confirm successful co-transfection of the cDNA for GluR1 and GluR2. GluR1/2 transfected HEK cells do not show the rectification observed in HEK cells transfected with GluR1 alone (Figure 2-1). Only cells with a ratio of current at $+40 \mathrm{mV}$ to $-60 \mathrm{mV}$ of approximately 0.4 or more were included in data analysis (Burnashev et al. 1995). Data analysis was performed using Clampfit (Axon Instruments; Foster City, CA), and Origin Pro 7.0 (Microcal; Northhampton, MA). All data are displayed as mean +/- s.e.m. 
A.

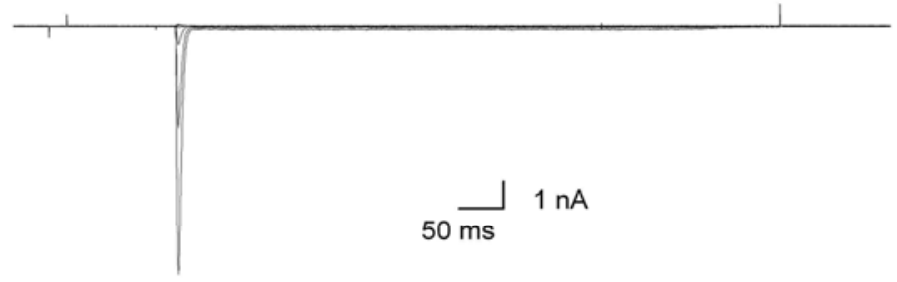

B.
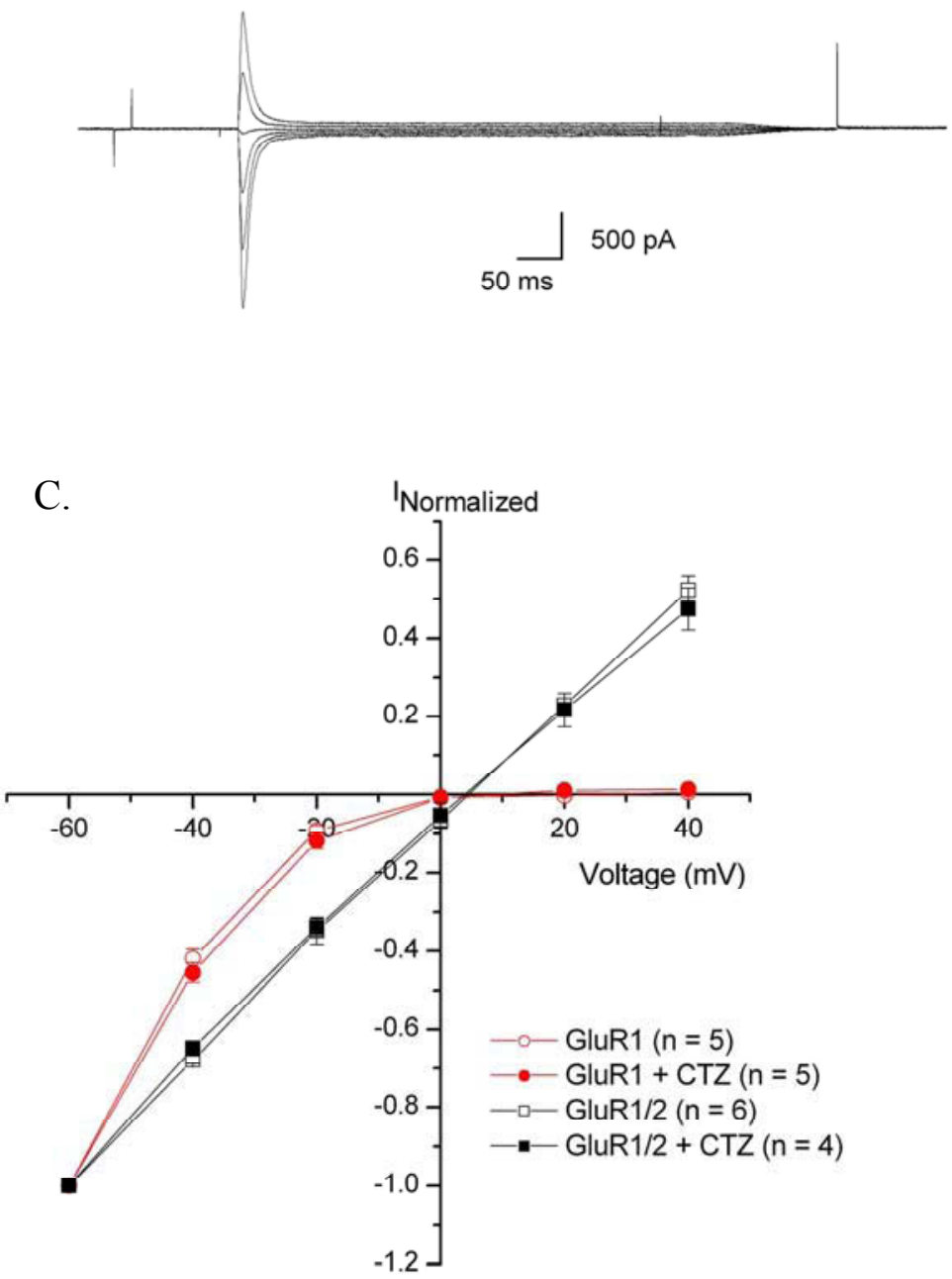

Figure 2-1 Current-Voltage Relationship for GluR1 and GluR1/2 Transfected Cells

HEK cells were transfected with GluR1 +/- GluR2. (A) Representative current traces for GluR1 at various holding potentials in response to I-V protocol $(-60 \mathrm{mV}$ to $+40 \mathrm{mV})$. (B) Representative traces for GluR1/2. (C) Average I-V relationships are shown in response to the I-V protocol $(-60 \mathrm{mV}$ to $+40 \mathrm{mV}$ ) for GluR1 (red) and GluR1/2 (black) in the absence (open) or presence (filled) of the desensitization blocker CTZ $(100 \mu \mathrm{M})$ 


\section{CHAPTER 3. RESULTS}

\subsection{L-Proline is a Low Affinity Agonist at Recombinant AMPA Receptors}

Previous work suggests that 1-proline is a very low affinity agonist at glutamate receptors in rat spinal cord neurons (Henzi et al. 1992). However 1-proline can dramatically affect hippocampal excitatory transmission at much lower concentrations (Cohen and Nadler 1997). The pharmacological action of proline at glutamate receptors therefore remains unclear. This stems, in part, from the unknown receptor subtypes or stoichoimetry of glutamate receptors that exist in these neurons. Thus, experiments were designed to determine the sensitivity of 1-proline at recombinant AMPA-type glutamate receptors. Homomeric GluR1 and heteromeric GluR1/2 receptors were examined because these are the prevailing AMPA receptors in the hippocampus (Wenthold et al. 1996).

To determine the efficacy of 1-proline as an agonist relative to glutamate, the dose-response relationship with 1-proline was determined for GluR1 and GluR1/2 receptors and compared to a saturating concentration of glutamate $(10 \mathrm{mM})$. The effectiveness of 1-proline in inducing current at GluR1 and GluR1/2 is dose-dependent as shown by its ability to induce greater currents at higher concentrations. At a concentration of $10 \mathrm{mM}$, 1-proline elicited a current of $0.559 \pm 0.141 \%$ and $1.166 \pm$ $0.223 \%$ of the initial current induced by the application of $10 \mathrm{mM}$ glutamate at GluR1 and GluR1/2 receptors respectively (Figure 3-1). Because the currents elicited with the application of 1-proline were small, cyclothiazide (CTZ), a blocker of desensitization (Yamada and Tang 1993), was applied in order to enhance detection of proline-evoked currents. Current evoked by $10 \mathrm{mM}$ 1-proline at heteromeric GluR1/2 receptors were significantly enhanced by the presence of $100 \mu \mathrm{M} \mathrm{CTZ}(4.005 \pm 0.38 \%, \mathrm{n}=5, \mathrm{p}<$ $0.001)$. However, even at $10 \mathrm{mM} 1$-proline generated current was less than $5 \%$ of the initial $10 \mathrm{mM}$ glutamate-induced current at GluR1/2 receptors. Co-application of $10 \mathrm{mM}$ 1-proline and CTZ increased current generated at GluR1 receptor to $2.045 \pm 0.583 \%$ of initial $10 \mathrm{mM}$ glutamate-induced current.

Consistent with the known actions of CTZ to increase current flow due to a reduction in desensitization (Yamada and Tang 1993), application of CTZ increased the current density in GluR1 and GluR1/2-expressing cells (Figure 3-2). Where current density is calculated as follows:

$$
\text { Current density }=\frac{\text { Total Current }(\mathrm{pA})}{\text { Membrane capacitance }(\mathrm{pF})}
$$

Application of CTZ was also shown to not alter the I-V relationship, a physiological property used in distinguishing between GluR 1 and GluR $1 / 2$ receptors as shown in Figure 2-1. These results support previous study (Henzi et al. 1992) that have shown 1-proline to be very low affinity agonist at glutamate receptors. 
A.

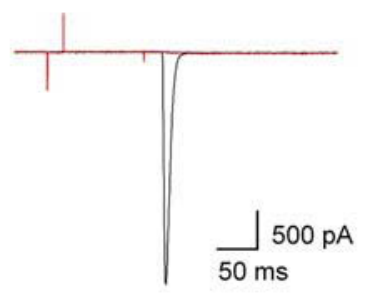

C.

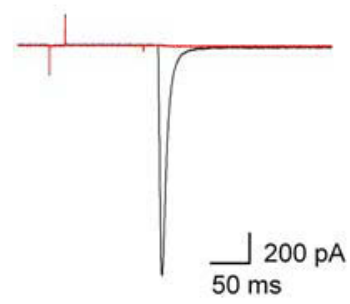

B.

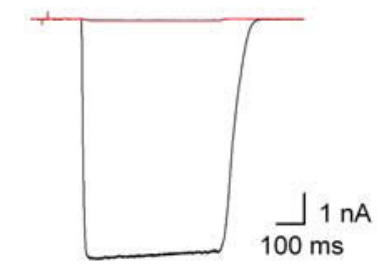

D.

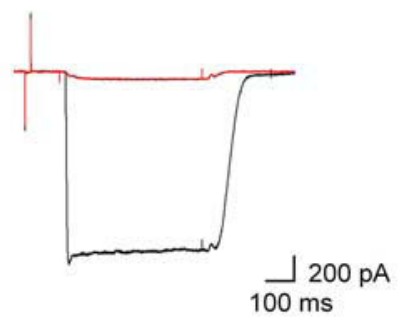

E.

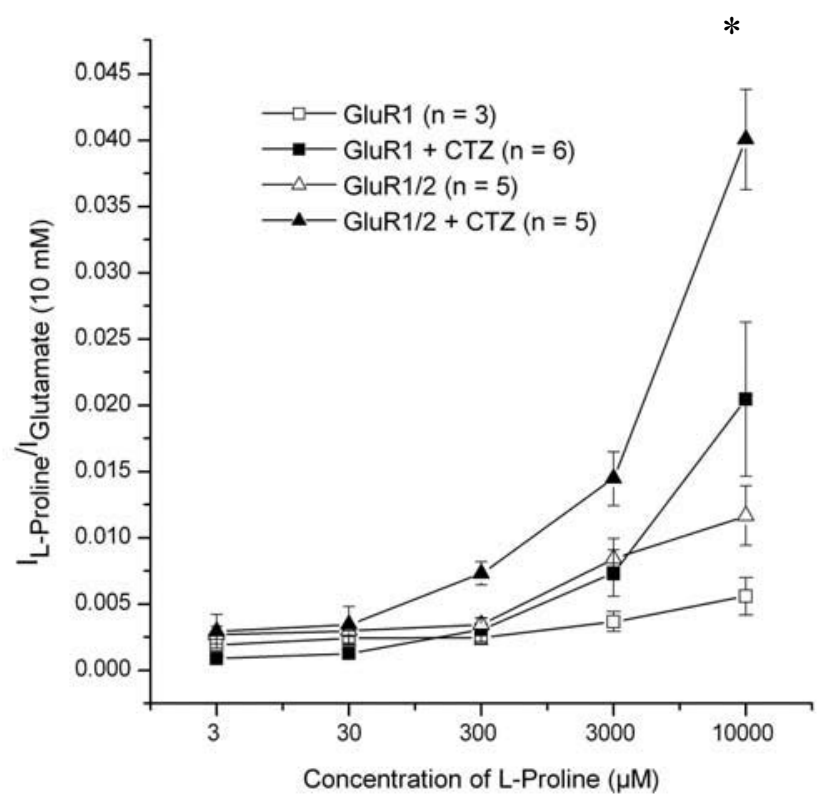

Figure 3-1 L-proline Dose Response for GluR1 and GluR1/2

Whole-cell recordings of GluR1 and GluR1/2 receptor currents expressed in HEK 293 cells. Currents are evoked by $500 \mathrm{~ms}$ application of $10 \mathrm{mM}$ glutamate or $3 \mu \mathrm{M}, 30 \mu \mathrm{M}$, $300 \mu \mathrm{M}, 3 \mathrm{mM}$ and $10 \mathrm{mM}$ 1-proline. (A) Representative traces to the initial $10 \mathrm{mM}$ glutamate application (black) and to application of $10 \mathrm{mM}$ 1-proline in GluR1 receptors (red). (B) Same as A, in the presence of CTZ. (C) Representative traces to the initial 10 $\mathrm{mM}$ glutamate application (black) and to application of $10 \mathrm{mM}$ 1-proline in GluR1/2 receptor. (D) Same as C, in the presence of CTZ. (E) Summary graph showing the doseresponse of the l-proline peak current normalized to current induced with $10 \mathrm{mM}$ Glutamate (not shown) for different concentration of 1-proline ( $3 \mu \mathrm{M}$ to $10 \mathrm{mM})$ with GluR1 (open square), GluR1 in the presence of CTZ (filled square), GluR1/2 (open triangle) and GluR1/2 in the presence of CTZ (filled triangle) where $n$ indicated in parenthesis is the number of observations. 


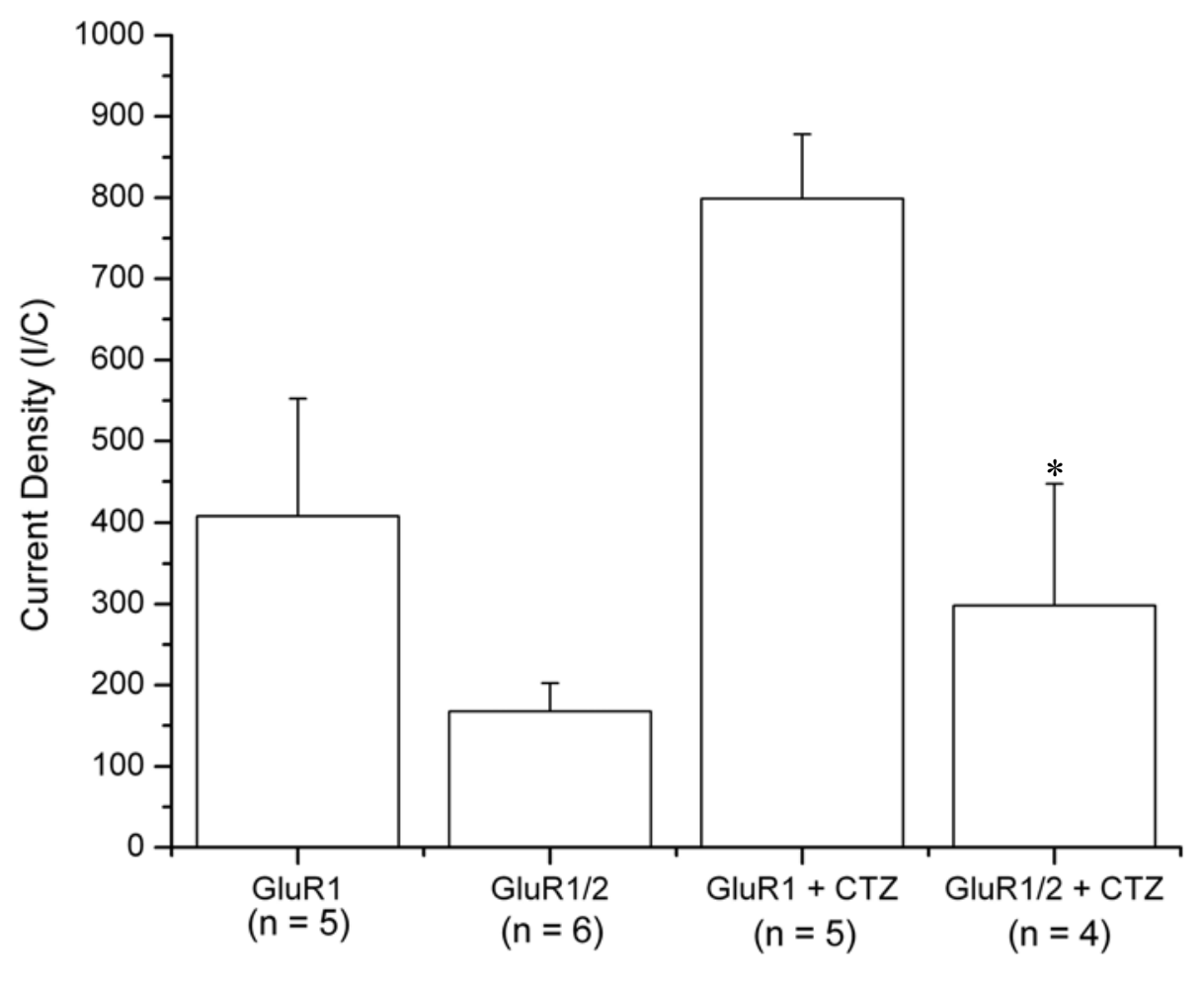

Receptor type and condition

Figure 3-2 Current Density of GluR1 and GluR1/2

HEK 293 cells were transfected with GluR $1 \pm$ GluR1/2. Current densities of GluR1 and GluR1/2 receptors in the presence or absence of CTZ measured using glutamate $(10 \mathrm{mM})$ as an agonist at a holding potential $-60 \mathrm{mV}$. 
In hyperprolinemia 1-proline concentrations are elevated 10-fold in the cerebrospinal fluid to approximately $30 \mu \mathrm{M}$ (Phang et al. 2001). This study hypothesized that the persistent increase in 1-proline level may affect glutamate signaling at glutamate receptors. To test this hypothesis, the effect of tonic physiological $(3 \mu \mathrm{M})$ and pathophysiological $(30 \mu \mathrm{M})$ 1-proline levels on glutamate-induced currents at GluR1 and GluR1/2 receptors were examined.

Application of $30 \mu \mathrm{M}$ 1-proline was found to result in a statistically significant ( $\mathrm{p}$ $<0.05)$ decrease in current generated by the application of $10 \mathrm{mM}$ of glutamate (23.6 $10.0 \% ; \mathrm{n}=5$ ) (Figure 3-3). In contrast, there was no significant decrease in current induced with the application of $10 \mathrm{mM}$ glutamate in the presence of $3 \mu \mathrm{M}$ 1-proline $(1.8 \pm$ $8.5 \% ; \mathrm{n}=6$ ). Application of $30 \mu \mathrm{M}$ 1-proline lead to a slight shift in the kinetics of the channel as shown by a delay in the activation rate with application of $10 \mathrm{mM}$ of glutamate in the presence of $30 \mu \mathrm{M}$ of 1-proline. These findings indicate that the tonic presence of pathophysiological but not physiological concentration of 1-proline resulted in a disruption of the ability of glutamate to activate homomeric GluR1 receptors. This result suggests that 1-proline, acting as a partial agonist, reduced the agonist effect of glutamate by competing with glutamate for the receptors. Alternatively, 1-proline could be responsible for driving the GluR1 receptors into a state of desensitization. These findings were however consistent with the reduction in agonist activity when assessed in the presence of a partial agonist. Thus, tonic pathophysiological concentrations of 1proline as encountered in hyperprolinemia may contribute to glutamate receptor hypofunction.

With heteromeric GluR $1 / 2$ receptors, there was no significant change in the current with the application of physiological $(-3.534 \pm 4.9975 \% ; n=5)$ or pathophysiological $(6.4360 \pm 4.8742 \% ; n=6)$ concentrations of l-proline when compared to control (Figure 3-4). Co-application of pathophysiological $30 \mu \mathrm{M}$ 1-proline with $10 \mathrm{mM}$ glutamate was previously shown to lead to a slight shift in the kinetics of GluR1 homomeric receptors. However, under the same conditions no change in the kinetics of GluR $1 / 2$ heteromeric receptors was observed. Taken together, these findings suggest that although 1-proline induced a greater current in GluR1/2 receptors than GluR1 receptors, tonic application of pathophysiological concentrations of 1-proline selectively suppressed the ability of glutamate to activate homomeric GluR1 AMPA receptors. Given that GluR1 receptors desensitized more completely than heteromeric GluR1/2 receptors, 1-proline may preferentially drive GluR 1 , but not GluR $1 / 2$, receptors into a state of desensitization.

\subsection{CTZ Application Blocks the Effect of Tonic L-Proline on GluR1 Currents}

To test if the reduction in glutamate-induced current in the tonic presence of pathophysiological l-proline is due to desensitization of the receptors, CTZ was applied through out the experiment. The aforementioned proline-induced decrease in the current 


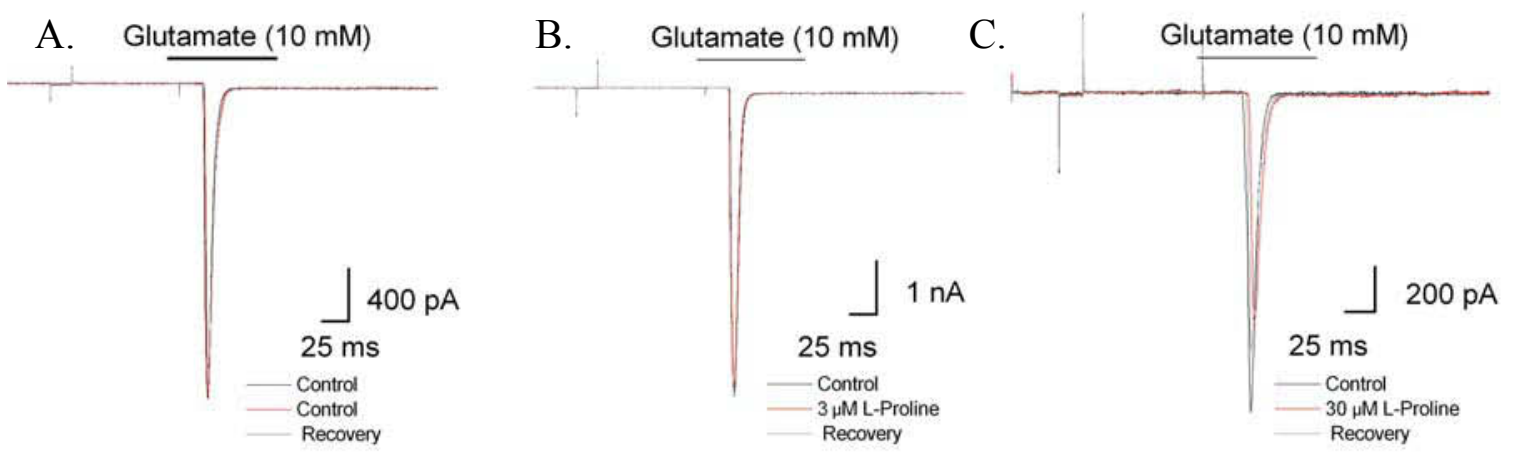

D.

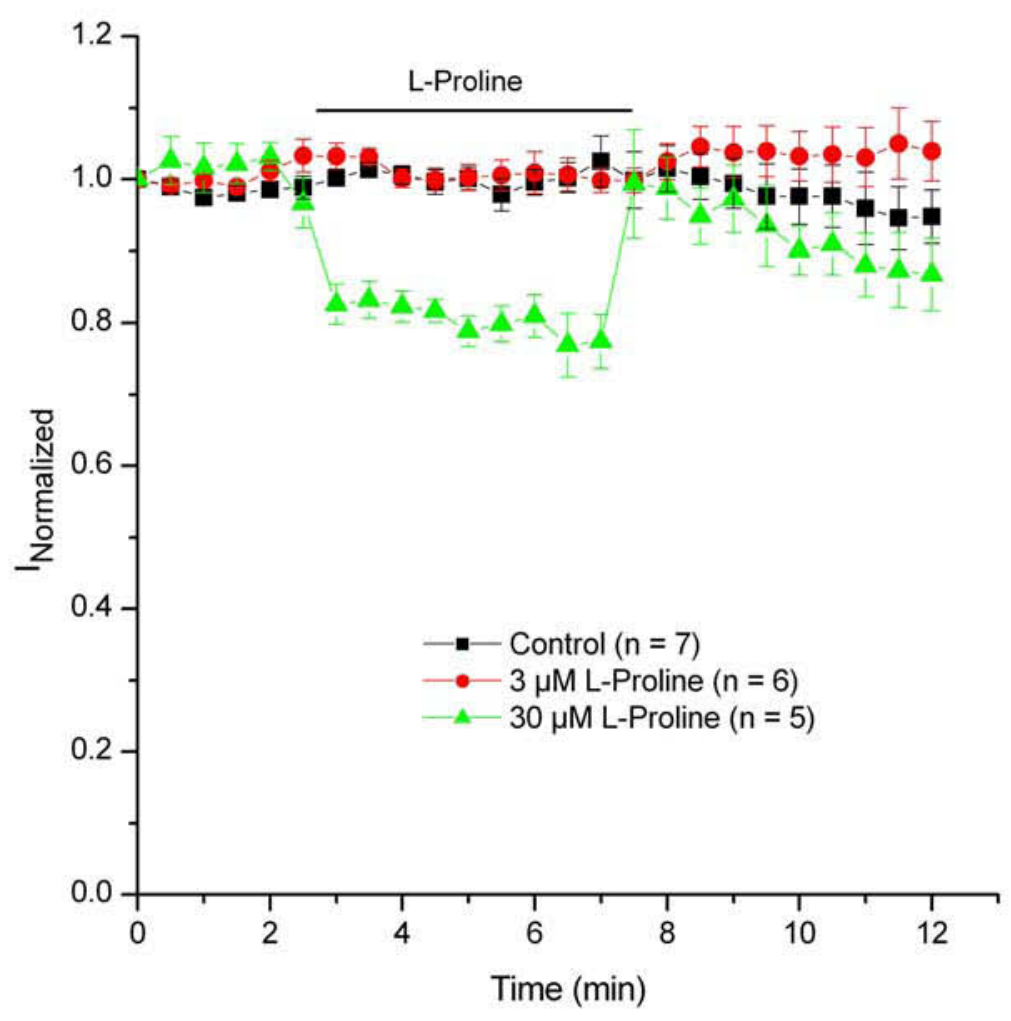

Figure 3-3 The Effect of Tonic L-Proline Levels on GluR1 Currents

HEK cells were transfected with GluR1 and GFP. Control whole cell recordings were made from cells exposed to control solution of $10 \mathrm{mM}$ glutamate (black), with subsequent co-application of $3 \mu \mathrm{M}$ 1-proline or $30 \mu \mathrm{M}$ 1-proline (red and green respectively). (A-C) Representative traces during application of $10 \mathrm{mM}$ glutamate (black) and application of $10 \mathrm{mM}$ glutamate in the presence of control $(0 \mu \mathrm{M}), 3 \mu \mathrm{M}$ and $30 \mu \mathrm{M}$ 1-proline respectively (red). (D) Summary graph showing the average time course of peak current normalized to the initial control pulse is plotted for coapplication of $3 \mu \mathrm{M}$ or 30 $\mu \mathrm{M}$ 1-proline concentrations with $10 \mathrm{mM}$ glutamate at GluR1. Where $\mathrm{n}$ indicated in parenthesis is the number of observations. 


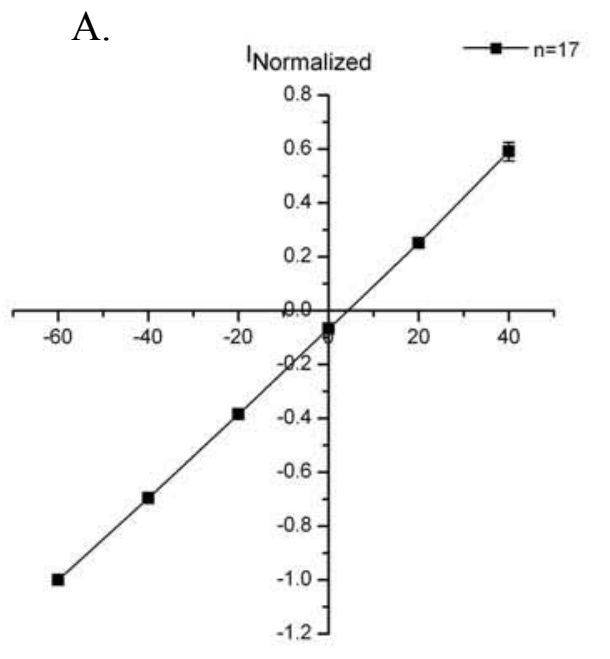

B.

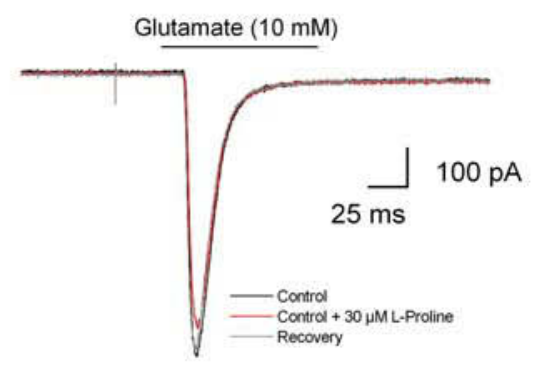

C.

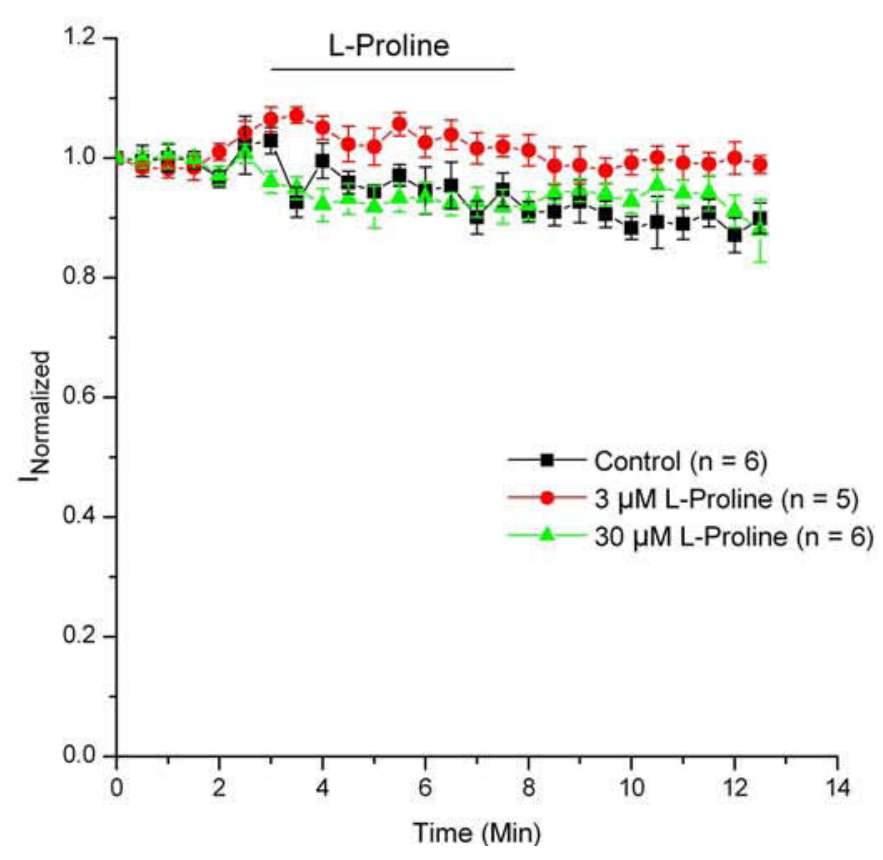

Figure 3-4 The Effect of Tonic L-Proline Levels on GluR1/2 Currents

HEK cells were transfected with GluR1, GluR2 and GFP. Control whole cell recordings were made from cells exposed to control solution of $10 \mathrm{mM}$ glutamate (black), $3 \mu \mathrm{M} 1-$ proline or $30 \mu \mathrm{M}$ 1-proline (red and green respectively). (A) Average I-V relationships are shown in response to I-V protocol $(-60 \mathrm{mV}$ to $+40 \mathrm{mV})$. The I-V relationships were generated with the same cells used in the experiments. (B) Representative traces during co-application of $30 \mu \mathrm{M}$ l-proline and $10 \mathrm{mM}$ glutamate (red) and to initial $10 \mathrm{mM}$ glutamate application (black) are shown. (C) Summary graph showing average time course for peak current normalized to the initial control pulse for co-application of $3 \mu \mathrm{M}$ or $30 \mu \mathrm{M}$ 1-proline concentrations with $10 \mathrm{mM}$ glutamate at GluR1/2 heteromeric receptors 
produced by $10 \mathrm{mM}$ glutamate at GluR1 receptors was abolished by the application of CTZ $(-3.3188 \pm 4.8352 \% ; \mathrm{n}=5)$ when compared with control in the absence of CTZ ($1.8860 \pm 6.6879 \% \mathrm{n}=7$ ). Data generated for $3 \mu \mathrm{M}$ and $30 \mu \mathrm{M}$ 1-proline are plotted on the same graph for visual comparison of the effect of $30 \mu \mathrm{M}$ 1-proline on GluR1 homomeric receptors in the presence and absence of CTZ (Figure 3-5). No change in the kinetics of the receptor was detected upon the co-application of CTZ and pathophysiological concentration of 1-proline. These findings suggest that the reduction of glutamate-evoked current by the tonic presence of a pathophysiological 1-proline concentration was due to the ability of 1-proline to drive homomeric GluR1 receptors into a desensitized state.

\subsection{Effect of Pathophysiological L-Proline Concentration on Paired-Pulse-Ratio in GluR1}

Previous studies have suggested that 1-proline decreased glutamate transmission by reducing glutamate release in rat cerebral cortex and hippocampus (Keller et al. 1981; Cohen and Nadler 1997). The ability of proline to decrease glutamatergic transmission in the hippocampus was determined using a paired-pulse assay, in which an increase in the paired-pulse ratio is interpreted as a reduction in the presynaptic release (Cohen and Nadler 1997). However, if 1-proline binds to glutamate receptors with a weak affinity, then a second pulse should compete off proline and generate a relatively larger current.

With glutamate a paired-pulse-ratio (ratio of second pulse to the first pulse) was computed at $0.34 \pm 0.03(\mathrm{n}=5)$ with the co-application of pathophysiological concentration of 1-proline $(30 \mu \mathrm{M})$ there was a significant increase in the paired pulse ratio to $0.47 \pm 0.04(\mathrm{p}<0.05)($ Figure 3-6). Therefore, an increase in the paired-pulseratio in the presence of pathophysiological concentration of 1-proline at GluR1 receptors occured. These findings suggest that the increase in paired-pulse-ratio previously observed in hippocampal neurons in response to pathophysiological concentrations of 1proline may not simply be a result of altered presynaptic function but may arise, in part, due to 1-proline-induced desensitization of GluR1. 
A.

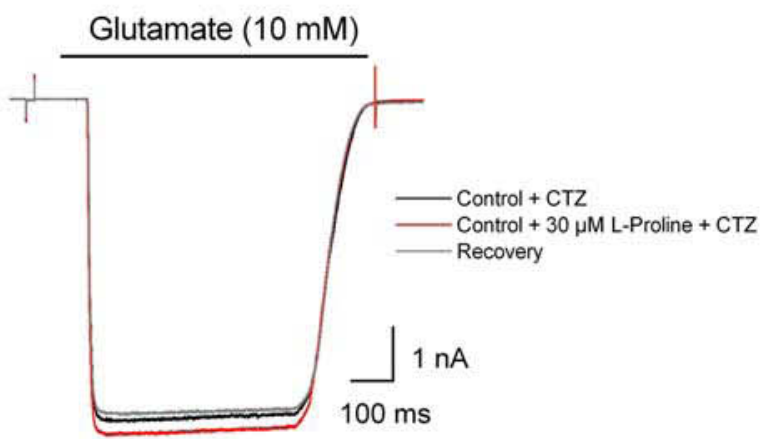

B.

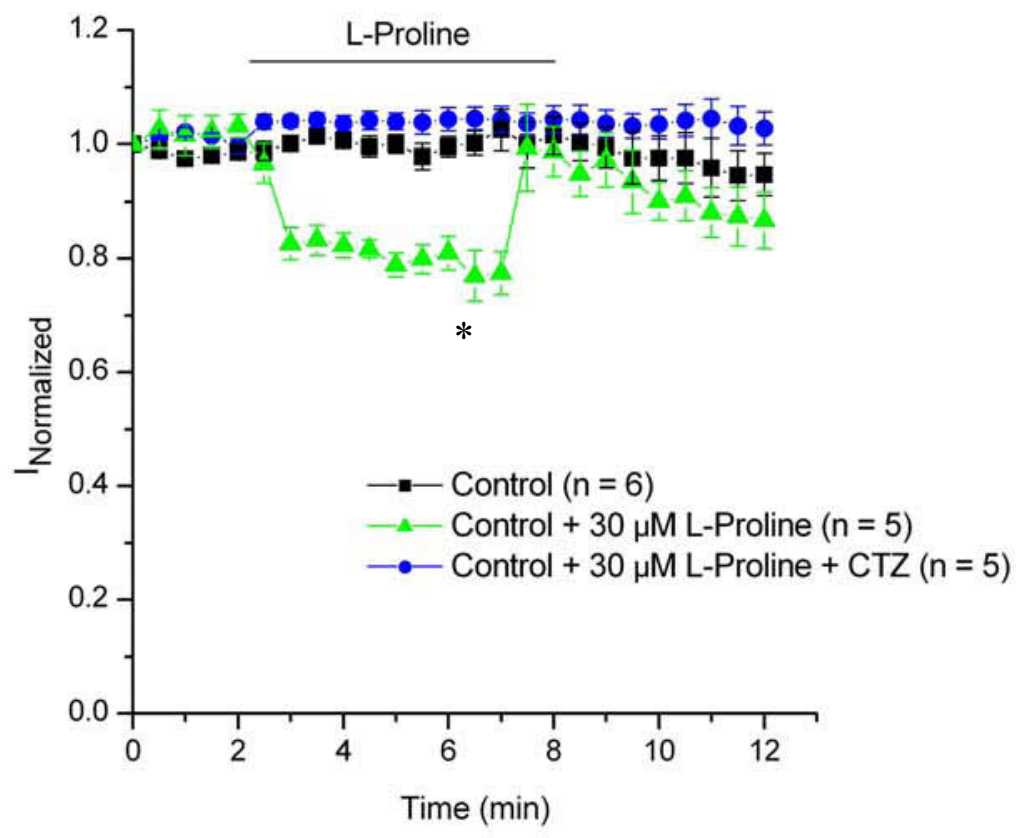

\section{Figure 3-5 CTZ Application Blocks the Effect of Tonic L-Proline on GluR1} Currents

HEK cells were transfected with GluR1 and GFP. Control whole cell recordings were made from cells exposed to control solution of $10 \mathrm{mM}$ glutamate (black), $3 \mu \mathrm{M}$ 1-proline (green) or $30 \mu \mathrm{M}$ 1-proline with CTZ present (blue). (A) Representative traces during coapplication of $10 \mathrm{mM}$ glutamate and $30 \mu \mathrm{M}$ 1-proline application (red) to the initial glutamate application (black) and at recovery (gray) in the presence of CTZ are shown. (B) Summary of the average time course of peak current normalized to the initial control pulse for co-application of $10 \mathrm{mM}$ glutamate and $30 \mu \mathrm{m}$ 1-proline in the presence or absence of CTZ at GluR1 receptors. Where $n$ indicated in parenthesis is the number of observations. 
A.
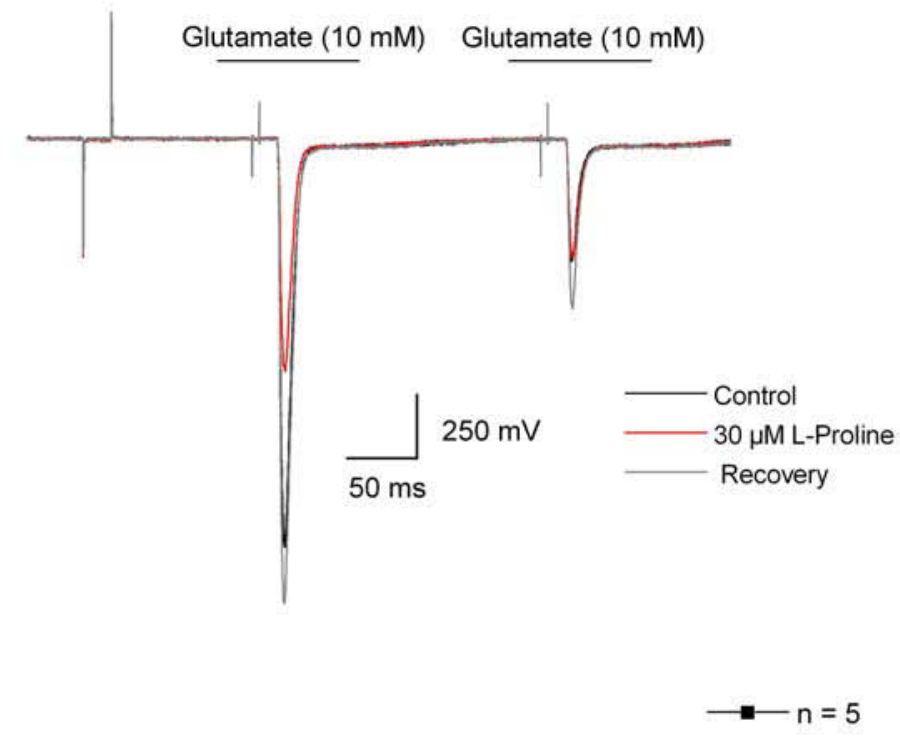

B.

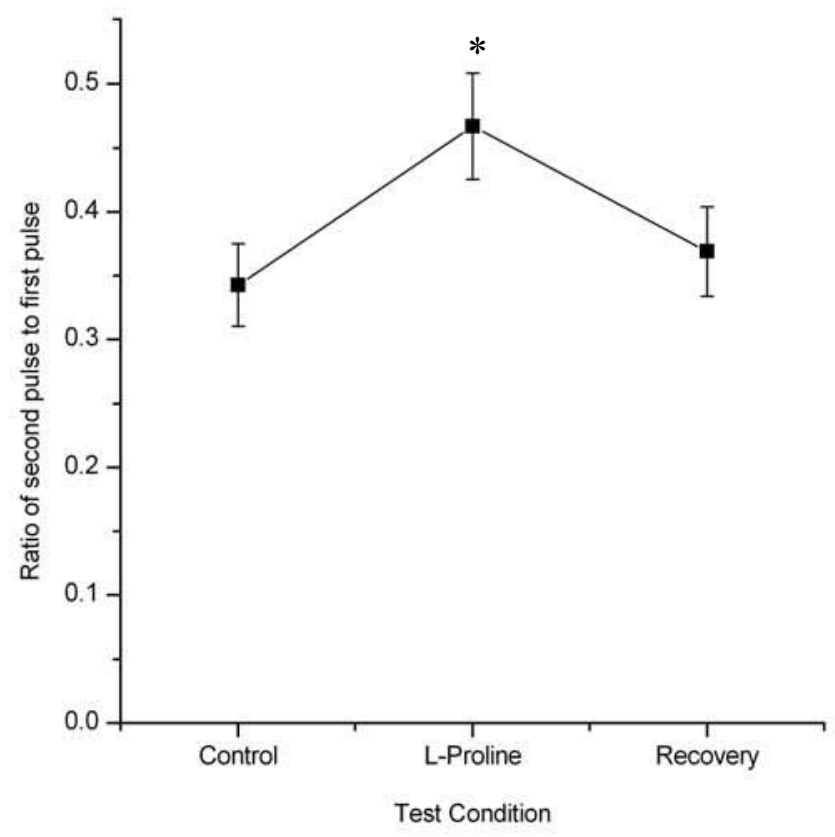

Figure 3-6 Effect of Pathophysiological L-Proline Concentration on PairedPulse-Ratio in GluR1

HEK cells were transfected with GluR1 and GFP exposed to $25 \mathrm{~ms}$ pulse of $10 \mathrm{mM}$ glutamate (control) or $10 \mathrm{mM}$ glutamate and $30 \mu \mathrm{M}$ l-proline. (A) Representative traces to the initial paired pulse in the presence of control (10 mM glutamate) (black), control and $30 \mu \mathrm{M}$ 1-proline (red) and recovery (grey) are shown. (B) Average of ratio of second pulse to the first pulse plotted against test conditions; in the presence of $10 \mathrm{mM}$ glutamate (control), $10 \mathrm{mM}$ glutamate and $30 \mu \mathrm{M}$ l-proline and recovery. 


\section{CHAPTER 4. DISCUSSION}

\subsection{L-Proline as a Partial Agonist at Recombinant AMPA Receptors}

Consistent with previous studies which suggested that l-proline is low affinity agonist at native NMDA and non-NMDA glutamate receptors (Henzi et al. 1992), the data presented here confirm that 1-proline exhibits a low efficacy at recombinant AMPA receptors composed of homomeric GluR 1 and heteromeric GluR $1 / 2$ receptors. Indeed, 10 $\mathrm{mM}$ 1-proline elicited less than $2.5 \%$ of the current evoked by the full agonist at the same concentration in either of the receptors. Thus, these data are consistent with an estimated EC50 of above $50 \mathrm{mM}$ for 1-proline at native glutamate receptors and are consistent with 1-proline acting as a partial agonist (Henzi et al. 1992). Given that 1-proline generates less than $2.5 \%$ of the maximum available current at a concentration of $10 \mathrm{mM}$, pathophysiological and physiological concentrations of 1-proline will be expected to produce negligible direct excitation of native AMPA receptors. Rather, the actions of 1proline at pathophysiological levels may be to dampen glutamate-mediated activation of AMPA receptors which is also consistent with a partial agonist profile for proline.

\subsection{L-Proline Disruption of Glutamate-Induced Current at Recombinant Glutamate Receptors}

A previous study has shown that 1-proline at both physiological and pathophysiological potentiates glutamate transmission (Cohen and Nadler 1997). This effect could have been as a result of the wide repertoire of glutamate receptors expressed by the brain slices or the possibility that the 1-proline induced potentiation of the fEPSP was mediated through other targets (Henzi et al. 1992; Cohen and Nadler 1997). Although 1-proline exhibited negligible activation of the recombinant AMPARs in the pathophysiological to pathophysiological range, the tonic presence of pathophysiological 1-proline selectively disrupted the ability of glutamate to activate homomeric GluR1 receptors. Data generated from this study show a significant decrease of approximately $24 \%$ of glutamate-induced current at GluR1 receptors with the application of a pathophysiological relevant concentration of 1-proline. This decrease in glutamateinduced current was however not observed in the presence of physiological concentration of 1-proline. This suggests that the increases in 1-proline level observed in hyperprolinemia leads to a decrease in glutamate-induced current at GluR 1 receptors and could be relevant in the hypoglutamatergic theory of schizophrenia. Indeed, this is consistent with the schizophrenic behavior in animals lacking GluR1 (Wiedholz et al. 2008).

Interestingly 1-proline acts differently at homomeric GluR1 and heteromeric GluR1/2 receptors, indicating a pharmacological difference between the two receptors. Moreover, the ability of homomeric GluR1 receptors to be selectively targeted may be particularly relevant for schizophrenia. Indeed these receptors tend to be preferentially expressed on interneurons (Geiger et al. 1995; Rossi et al. 2008). Reduction in the 
activity of these neurons has been proposed to be critical for schizophrenia (Belforte et al. 2010).

\subsection{L-Proline Desensitization of GluR1 Receptors}

The proline-induced reduction in glutamate-induced current observed at GluR1 receptors was abolished by the application of CTZ. These findings, as well as data generated from the paired-pulse ratio experiment suggest 1-proline acts by binding at homomeric GluR1 receptors and at least at pathophysiological concentration by inducing significant desensitization of the receptor. Interestingly, the increase in Paired-pulse-ratio due to pathophysiological 1-proline described by Cohen and Nadler (1997) was approximately $50 \%$, which is similar to the approximately $38 \%$ increased observed in response to a similar protocol in the recombinant system employed. Thus, contrary to a previous study suggesting that the 1-proline-induced increase in paired-pulse ratio observed on native receptors in hippocampal slices is through a reduction in pre-synaptic glutamate release; the data presented here indicate a postsynaptic mechanism by which 1proline induces a decrease in glutamate-induced current at GluR1 receptor through desensitization of the receptor. This is particularly interesting as a recent study has suggested that $\mathrm{Ca}^{2+}$-permeable AMPA receptors (which are presumably GluR1 homomers) reside in the perisynaptic space (He et al. 2009). The presence of these $\mathrm{Ca}^{2+}$ permeable AMPA receptors are preferentially revealed by paired pulse stimulation protocols (He et al. 2009). Thus, the ability of 1-proline to induce an increase in paired pulse ratio is consistent with the selective regulation of homomeric GluR1 AMPA receptors described here.

As shown in this study 1-proline has differential effect on glutamate-induced current at two different AMPA receptors, thus the possibility exists that 1-proline acts at other types of glutamate receptors including NMDA receptors which are important in a subunit specific manner for learning and memory. Indeed, one can expect these findings to be extended to other glutamate receptors and thus, the possibility that 1-proline could also account for glutamate hypofunction at these receptors. 


\section{CHAPTER 5. CONCLUSION}

The experiments carried out in this study were designed with a view to determining the role of 1-proline as an agonist, as well as the implications of hyperprolinemia at two recombinant AMPA receptors. Specifically, to determine the differential effect of tonically present physiological versus pathophysiological concentration of 1-proline on the ability of glutamate to bind to and activate GluR1 homomeric and GluR1/2 heteromeric receptors. A decrease in glutamate-induced current was observed with the application of pathophysiological concentration of 1-proline (30 $\mu \mathrm{M})$ when compared to the physiological concentration $(3 \mu \mathrm{M})$. This decrease was not observed with the same concentration in GluR $1 / 2$ heteromeric receptors. L-proline was shown to induce a larger current at GluR1/2 heteromeric receptors than at GluR1 homomeric receptors, however the current induced at $30 \mu \mathrm{M}$ (pathophysiological concentration) of 1-proline is shown to be statistically insignificant.

The reduction in glutamate-induced current in the tonic presence of pathophysiological concentration of 1-proline was shown to be due to desensitization of the receptor. The differences in the ability of 1-proline to induce desensitization at GluR1 homomeric receptors and its ability to induce currents at GluR1/2 heteromeric and GluR1 homomeric receptors may provide a foundation to the understanding of how l-proline affects glutamate transmission. The ability of pathophysiological concentrations of 1proline to induce a decrease in glutamate-induced current at homomeric GluR1 receptors may be a relevant mechanism by which hyperprolinemia contributes to schizophrenia. 


\section{LIST OF REFERENCES}

Abe T, Sugihara H, Nawa H, Shigemoto R, Mizuno N, Nakanishi S (1992). Molecular characterization of a novel metabotropic glutamate receptor mGluR5 coupled to inositol phosphate/ $\mathrm{Ca}^{2+}$ signal transduction. J Biol Chem 267:13361-13368.

Afenjar A, Moutard M, Doummar D, Guet A, Rabier D, Vermersch A et al. (2007). Early neurological phenotype in 4 children with biallelic PRODH mutations. Brain Dev 29:547-552.

Alford S, Frenguelli BG, Schofield JG, Collingridge GL (1993). Characterization of $\mathrm{Ca}^{2+}$ signals induced in hippocampal CA1 neurones by the synaptic activation of NMDA receptors. J Physiol 469:693-716.

Alkon DL, Lederhendler I, Shoukimas J (1982). Primary changes of membrane currents during retention of associative learning. Science 215:693-695.

Anand R (2000). Probing the topology of the glutamate receptor GluR1 subunit using epitope-tag insertion. Biochem Biophys Res Commun 276:157-161.

Antonov I, Antonova I, Kandel ER, Hawkins RD (2003). Activity-dependent presynaptic facilitation and Hebbian LTP are both required and interact during classical conditioning in Aplysia. Neuron 37:135-147.

Armstrong N, Sun Y, Chen GQ, Gouaux E. (1998). Structure of a glutamate receptors ligand-binding core in complex with kainaite. Nature 395:913-917.

Ayalon G, Stern-Bach Y (2001). Functional assembly of AMPA and kainite receptors is mediated by several discrete protein-protein interactions. Neuron 31:103-113.

Belforte JE, Zsiros V, Sklar ER, Jiang Z, Yu G, Li Y et al (2010). Postnatal NMDA receptor ablation in corticolimbic interneurons confers schizophrenia-like phenotypes. Nat Neurosci 13:76-83.

Bender H, Almashanu S, Steel G, Hu CA, Lin WW, Willis A et al (2005). Functional consequences of PRODH missense mutations. Am J Hum Genet 76:409-420.

Bennet J, Dingledine R (1995). Topology profile for a glutamate receptor: Three transmembrane domains and a channel-lining reentrant membrane loop. Neuron 14:373384.

Bernareggi A, Duenas Z, Reyes-Ruiz J, Ruzzier F, Miledi R (2006). Properties of glutamate receptors in Alzheimer's disease brain transplanted to frog oocytes. Proc Natl Acad Sci U S A 104:2956-2960. 
Bertolo RF, Burrin DG (2008). Comparative aspects of tissue glutamine and proline metabolism. J Nutr 138:2032S-2039S.

Bliss TVP, Lomo T (1973). Long-lasting potentiation of synaptic transmission in the dentate area of the anaesthetized rabbit following stimulation of the perforant path. $J$ Physiol Lond 232:331-356.

Borbely S, Dobo E, Czege D, Molnar E, Bakos M, Szucs B, et al (2009). Modification of ionotropic glutamate receptor-mediated processes in the rat hippocampus following repeated brief seizures. Neuroscience 159:358-368.

Boulter J, Hollmann M, O'Shea-Greenfield A, Hartley M, Deneris E, Maron C, Heinemann S (1990). Molecular cloning and functional expression of glutamate receptor subunit genes. Science 249:1033-1037.

Burnashev N, Zhou Z, Neher E, Sakmann B (1995). Fractional calcium currents through recombinant GluR channels of the NMDA, AMPA and kainite receptor subtypes. J Physiol 485:403-418.

Burnashev N, Villarroel A, Sakmann B (1996). Dimensions and ion selectivity of recombinant AMPA and kainate receptor channels and their dependence on $Q / R$ site residues. J Physiol 496:165-173.

Campbell H, Webb G, Young I (1997). A human homologue of the Drosophila melanogaster sluggish-A (proline oxidase) gene maps to 22q11.2, and is a candidate gene for type-I hyperprolinemia. Hum Genet 101:69-74.

Cha J, Kosinski C, Kerner J, Alsdorf S, Mangiarini L, Davies S et al (1998). Altered brain neurotransmitter receptors in transgenic mice expressing a portion of an abnormal human Huntington disease gene. Proc Natl Acad Sci U S A 95:6480-6485.

Chen C, Okayama H (1987). High-efficiency transformation of mammalian cells by plasmid DNA. Mol Cell Biol 7:2745-2752.

Christie J, Jahr C (2008). Dendritic NMDA receptors activate axonal calcium channels. Neuron 60:298-307.

Cohen S, Nadler J (1997). Proline-induced potentiation of glutamate transmission. Brain Res 761:271-282.

Davis JL, Pico RM, Flood JF (1987). Differences in learning between hyperprolinemic mice and their congenic controls. Behav Neural Biol 48:128-137.

Dawson T, Nicholas R, Dingledine R (1990). Homomeric GluR1 excitatory amino acid receptors expressed in Xenopus oocytes. Mol Pharmacol 38:779-784. 
Delwing D, Bavaresco CS, Clovis MD, Wannamacher MW, Carlos SD-F, Wyse A.T.S. (2003). Proline induces oxidative stress in cerebral cortex of rats. Int J Dev Neurosci 21:105-110.

Delwing D, Delwing D, Chiarani F, Kurek AG, Wyse ATS (2008). Proline reduces brain cytochrome c oxidase: prevention by antioxidants. Int J Dev Neurosci 25:17-22.

Diamond JS (2001). Neuronal glutamate transporters limit activation of NMDA receptors by neurotransmitter spillover on CA1 Pyramidal Cells. J Neurosci 21:8328-8338.

Di Rosa G, Pustorino G, Spano M, Campion D, Calabro M, Aguennouz M et al (2008). Type I hyperprolinemia and proline dehydrogenase (PRODH) mutations in four Italian children with epilepsy and mental retardation. Psychiatr Genet 18:40-42.

Dingledine R, Borges K, Bowie D, Traynelis S (1999). The glutamate receptor ion channels. Pharmacol Rev 51:7-62.

Du J, Creson T, Wu L-J, Ren M, Gray N., Falke C et al (2008). The role of hippocampal GluR1 and GluR2 receptors in manic-like behavior. J Neurosci 28:68-79.

Eastwood SL, McDonald B, Burnet PWJ, Beckwith JP, Kerwin RW, Harrison PJ (1995). Decreased expression of mRNAs encoding non-NMDA glutamate receptors GluR1 and GluR2 in medial temporal lobe neurons in schizophrenia. Brain Res Mol Brain Res 29:211-223.

Flynn M, Martin M, Moore P, Stafford J, Fleming G, Phang J (1989). Type II hyperprolinaemia in a pedigree of Irish travellers (nomads). Arch Dis Child 64:16991707.

Geiger JRP, Melch T, Koh DS, Sakmann B, Seeburg PH, Jonas P, Monyer H (1995). Relative abundance of subunit mRNAs determines gating and $\mathrm{Ca}^{2+}$ permeability of AMPA receptors in principal neurons and interneurons in rat CNS. Neuron 15:193-204.

Gibb A J, Colquhoun D (1991). Glutamate activation of a single NMDA receptor-channel produces a cluster of channel openings. Proc Biol Sci 243:39-45.

Goodman B, Rutberg J, Lin W, Pulver A, Thomas G, Geraghty M. (2000). Hyperprolinemia in patients with deletion (22)(q11.2) syndrome. J Inherit Metab Dis 23:847-848.

Hauptmann M. Wilson DF, Ereciriska M (1983). High affinity proline uptake in rat brain synaptosomes. FEBS Lett 161:301-305.

He K, Song L, Cummings LW, Goldman J, Huganir RL, Lee HK (2009). Stabilization of $\mathrm{Ca}^{2+}$-permeable AMPA receptors at perisynaptic sites by GluR1-S845 phosphorylation. Pro Natl Acad Sci U S A 106:20033-20038. 
Henzi V, Reichling D, Helm S, MacDermott A (1992). L-proline activates glutamate and glycine receptors in cultured rat dorsal horn neurons. Mol Pharmacol 41:793-801.

Hermes S, Mitchell J, Silverman M, Lynch P, Brenda L, Bailey T et al (2008). Sustained hypertention increases the density of AMPA receptor subunit, GluR1, in baroreceptive regions of the nucleus tractus solitarii of the rat. Brain Res 1187:125-136.

Heuss C, Scanziani M, Gahwiler B, Gerber U (1999). G-protein-independent signaling mediated by metabotropic glutamate receptors. Nat Neurosci 2:1070-1077.

Hires SA, Zhu Y, Tsien RY (2008). Optical measurement of synaptic glutamate spillover and reuptake by linker optimized glutamate-sensitive fluorescent reporters. Proc Natl Acad Sci U S A 105:4411-4416.

Hogner A, Kastrup JS, Jin R, Liljefors T, Mayer ML, Egebjerg J et al (2002). Structural basis for AMPA receptor activation and ligand selectivity: crystal structures of five agonist complexes with the Glur2 ligand-binding core. J Mol Biol 322:93-109.

Humbertclaude V, Rivier F, Rouertie A, Echenne B, Bellet H, Vallat C, Morin D (2001). Involvement and vigabatrin intolerance is hyperprolinemia type I actually a benign trait? Report of a case with severe neurologic. J Child Neurol 16:622-623.

Jacquet H, Raux G, Thibaut F, Hecketsweiler B, Houy E, Demilly C et al (2002). PRODH mutations and hyperprolinemia in a subset of schizophrenic patients. Hum Mol Genet 11:2243-2249.

Jacquet H, Demily C, Huoy E, Hecketsweiler B, Bou J, Raux G et al (2005).

Hyperprolinemia is a risk factor for schizoaffective disorder. Mol Psychiatry 10:479-485.

Jane DE, Lodge D, Collingridge GL (2009). Kainate receptors: Pharmacology, function and therapeutic potential. Neuropharmacology 56:90-113.

Jahr CE, Stevens CF (1993). Calcium permeability of the N-methyl-D-aspartate receptor channels in hippocampal neurons in culture. Proc Natl Acad Sci U S A 90:11573-11577.

Jin R, Banke TG, Mayer ML, Traynelis SF, Gouaux E (2003). Structural basis for partial agonist action at ionotropic glutamate receptors. Nat Neurosci 6:803-810.

Jones ME (1985). Conversion of glutamate to ornithine and proline: pyrroline-5carboxylate, a possible modulator of arginine requirements. J Nutr 115:509-15.

Jones MW, Errington ML, French PJ, Fine A, Bliss TVP, Garel S, Charnay P, Bozon B, Laroche S, Davis S. (2001). A requirement for the immediate early gene Zif268 in the expression of late LTP and the consolidation of long-term memories. Nat Neurosci 4:289-296. 
Katagiri H, Tanaka K, Manabe T (2001). Requirement of appropriate glutamate concentrations in the synaptic cleft for hippocampal LTP induction. J Neurosci 14:547553.

Kew J, Kemp J (2005). Ionotropic and metabotropic glutamate receptor structure and pharmacology. Psychopharmacology 179:4-29.

Keller E, Davis JL, Tachiki KH, Cummins JT, Baxter CF (1981). L-proline inhibition of glutamate release. J Neurochem 37:1335-1337.

Kessler A, Costabeber E, Dutra-Filho CS, Wyse ATS, Wajner M, Wanmacher CMD (2003). Proline reduces creatine kinase activity in the brain cortex of rats. Neurochem Res 28:1175-80.

Kussius CL, Popescu GK (2009). Kinetic basis of partial agonism at NMDA receptors. Nat Neurosci 12:1114-1122.

Lang UE, Puls I, Muller DJ, Strutz-Seebohm N, Gallinat J (2007). Molecular mechanisms of schizophrenia. Cell Physiol Biochem 20:689-702.

Lane D, Lessard A, Chan J, Colago E, Zhou Y, Schlussman S et al (2008). Regionspecific changes in the subcellular distribution of AMPA receptor GluR1 subunit in the rat ventral tegmental area after acute or chronic morphine administration. J Neurosci 28:9670-9681.

Lee H, Takamiya K, Han J, Man, H, Kim C, Rumbaugh G et al (2003). Phosphorylation of the AMPA receptor GluR1 subunit is required for synaptic plasticity and retention of spatial memory. Cell 112:631-643.

Li F, Owens N, Verdoorn T A (1995). Functional effects of mutations in the putative agonist binding region of recombinant $\alpha$-amino-3-hydroxy-5-methyl-4isoxazolepropionic acid receptors. Mol Pharmacol 47:148-154.

Li J, Zagotta WN, Lester HA (1997). Cyclic nucleotide-gated channels: structural basis of ligand efficacy and allosteric modulation. Q Rev Biophys 30:177-193.

Lipson A, Yuille D, Thompson P, Vandervoord J, Beckenham E (1991). Velocardiofacial (Shprintzen) syndrome: an important syndrome for dysmorphologist to recognize. J Med Genet 28:596-604.

Lisman JE, Coyle JT, Green RW, Javitt DC, Benes FM, Heckers S, Grace AA (2008).

Circuit-based framework for understanding neurotransmitter and risk gene interactions in schizophrenia. Trends Neurosci 31:234-242. 
Lomeli H, Mosbacher J, Melcher T, Hoger T, Geiger JRP, Kuner T et al (1994). Control of kinetic properties of AMPA receptor channels by nuclear RNA editing. Science 266:1709-1713.

Maltsev AS, Ahmed AH, Fenwick MK, Jane DE, Oswald RE (2008). Mechanism of partial agonism at the GluR2 AMPA receptor: Measurements of lobe orientation in solution. Biochemistry 47:10600-10610.

Mano I, Teichiberg V (1998). A tetrameric subunit stoichiometry for a glutamate receptor-channel complex. Neuroreport 9:327-331.

Mayer M, Westbrook G (1987). Permeation and block of n-methyl-d-aspartic acid receptor channels by divalent cations in mouse cultured central neurons. J Physiol 394:501-527.

Meldrum BS (2000). Glutamate as a neurotransmitter in the brain: review of physiology and pathology. J Nutr 130:1007S-1015S.

Miller RG, Jahoor F, Jaksic T (1995). Decreased cysteine and proline synthesis in parenterally fed, premature infants. J pediatr sugr 30:953-958.

Mitsubuchi H, Nakamura K, Matsumoto S, Endo F (2008). Inborn errors of proline metabolism. J Nutr 138:2016S-2020S.

Mohn AR, Gainetdinov RR, Caron MG, Koller BH (1999). Mice with reduced NMDA receptor expression display behaviors related to schizophrenia. Cell 98:427-436.

Murphy K, Jones L, Owen M (1999). High rates of schizophrenia in adults with velo cardio facial syndrome. Arch Gen Psychiatry 56:940-945.

Naur P, Vestergaard B, Skov L, Egebjerg J, Gajhede M and Kastrup J (2005). Crystal structure of the kainite receptor GluR5 ligand-binding core in complex with (S)glutamate. FEBS Lett 579:1154-1160.

National Institute of Mental Health NIMH. (2006) Schizophrenia. Bethesda, MD: U.S. Department of Health and Human Services. National Institutes of Health. NIH Publication No. 06-3517.

Okamoto N, Hori S, Akazawa C, Hayashi Y, Shigemoto R, Mizuno N, Nakanishim S (1994). Molecular characterization of a new metabotropic glutamate receptor mGluR7 coupled to inhibitory cyclic AMP signal transduction. J Biol Chem 269:1231-1236.

Ozawa S, Kamiya H, Tsuzuki K (1997). Glutamate receptor in the mammalian central nervous system. Prog Neurobiol 54:581-618. 
Pastalkova E, Serrano P, Pinkhasova D, Wallace E, Fenton AA, Sacktor TC (2006). Storage of spatial information by the maintenance mechanism of LTP. Science 313:11411144.

Petralia RS, Yokotani N, Wenthold RJ (1994). Light and Electron Microscope Distribution of the NMDA receptor subunit NMDARI in the rat nervous system using a selective anti-peptide antibody. J Neurosci 14:667-696.

Phang JM, Hu CA, Valle D (2001). Disorders of proline and hydroxyproline metabolism, in The metabolic and molecular basis of inherited disease, Scriver CR, Beaudet AR, Sly W, Valle D (eds)., McGraw-Hill: New York. p. 1821-1838.

Pontes ZL, Oliveira LS, Franzon R, Wajner M, Wannmacher CMD, Wyse ATS (2001). Inhibition of $\mathrm{Na}^{+}-\mathrm{K}^{+}$-ATPase activity from rat hippocampus by proline. Neurochem Res 26:1321-1326.

Popratiloff A, Weinberg RA, Rustioni A (1996). AMPA receptor subunits underlying terminals of fine-caliber primary afferent fibers. J Neurosci 16:3363-3372.

Purcell, A.E., Jeon, O.H., Zimmerman, A.W., Blue, M.E. and Pevsner, J. (2001). Postmortem brain abnormalities of the glutamate neurotransmitter system in autism. Neurology 57:1618-1628.

Ren Z, Riley NJ, Garcia EP, Sanders JM, Swanson GT, Marshall J (2003). Multiple trafficking signals regulate kainate receptor KA2 subunit surface expression. J Neurosci 23:6608-6616.

Renick SE, Kleven DT, Chan JC, Stenius K, Milner TA, Pickel VM, Fremeau Jr RT (1999). The mammalian brain high-affinity l-proline transporter is enriched preferentially in synaptic vesicles in a subpopulation of excitatory nerve terminals in rat forebrain. $\mathrm{J}$ Neurosci 19:21-33.

Riedel G, Platt B, Micheau J (2003). Glutamate receptor function in learning and memory. Behav Brain Res 140:1-47.

Rosenmund C, Stern-Bach Y, Stevens F (1998). The tetrameric structure of a glutamate receptor channel. Science 280:1596-1599.

Rossi B, Maton G, Collin T (2008). Calcium-permeable presynaptic AMPA receptors in cerebellar molecular layer interneurones. J Physiol 586.21:5129-5145.

Sanhueza, M., McIntyre, C.C. and Lisman, J.E. (2007). Reversal of synaptic memory by $\mathrm{Ca}^{2+} /$ calmodulin-dependent protein kinase II inhibitor. J Neurosci 27:5190 -5199.

Schlaepfer W, Bunge R (1973). Effects of calcium ion concentration on the degeneration of amputated axons in tissue culture. J Cell Biol 59:456-470. 
Shi S, Hayashi Y, Esteban J, Malinow R (2001). Subunit-specific rules governing AMPA receptor trafficking to synapses in hippocampal pyramidal neurons. Cell 105:331-323.

Shprintzen R, Goldberg R, Lewin M, Sidoti E, Berkman M, Argamaso R, Young D (1978). A new syndrome involving cleft palate, cardiac anomalies, typical facies and learning disabilities: velo-cardio-facial syndrome. Cleft Palate J 15:56-62.

Tanaka K, Graham S, Simon R (1996). The role of excitatory neurotranmitters in seizureinduced neuronal injury in rats. Brain Res 737:59-63.

Traynor JR, Clark MJ, Remmers AE (2002). Relationship between rate and extent of G protein activation: comparison between full and partial opiod agonists. J Pharmacol Exp Ther 300:157-161.

Tsien JZ, Huerta PT, Tonegawa S (1996). The essential role of hippocampal CA1 NMDA receptor-dependent synaptic plasticity in spatial memory. Cell 87:1327-1338.

Tymianski M, Charlton MP, Carlen PL, Tator CH (1993). Source specificity of early calcium neurotoxicity in cultured embryonic spinal neurons. J Neurosci 13:2085-2104.

Valle DL, Goodman SI, Applegarth DA, Shih VE, Phang JM (1976). Type II hyperprolinemia: [Delta] ${ }^{1}$-pyrroline-5-carboxylic acid dehydrogenase deficiency in cultured skin fibroblasts and circulating lymphocytes. J Clin Invest 58:598-603.

Velaz-Faircloth M, Guadano-Ferraz A, Henzi VA, Fremeau RT, (1995). Mammalian brain-specific 1-proline transporter. Neuronal localization of mRNA and enrichment of transporter protein in synaptic plasma membranes. J Biol Chem 270:15755-15761.

Verdoon TA, Burnashev N, Monyer H, Seeburg PH Sakmann B (1991). Structural determinants of ion flow through recombinant glutamate receptor channels. Science 252:1715-1718.

Vianna LP, Delwing D, Kurek AG, Breier AC, Kreutz F, Chiarani F (2008). Effects of chronic proline administration on lipid contents of rat brain. Int J Dev Neurosci 26:567573.

Wafford KA, Kathoria M, Bain CJ, Marshall G, Le Bourdelles B, Kemp JA, Whiting PJ (1995). Identification of amino acids in the N-methyl-D-aspartate receptor NR1 subunit that contribute to the glycine binding site. Mol Pharmacol 47:374-380.

Watkins J (2000). L-glutamate as a central neurotransmitter: Looking back. Biochem Soc Trans 28:297-309.

Wenthold RJ, Petralia RS, Blahos II J, Niedzielski AS (1996). Evidence for multiple AMPA receptor complexes in hippocampal CA1/CA2 neurons. J Neurosci 16:1982-1989. 
Whitlock JR, Heynen AJ, Shuler MG, Bear MF (2006). Learning induces long-term potentiation in the Hippocampus. Science 313:1093-1097.

Wiedholz LM, Owens WA, Horton RE, Feyder M, Karlsson RM, Hefner K et al (2008). Mice lacking the AMPA GluR1 receptor exhibit striatal hyperdopaminergia and 'schizophrenia-related' behaviors. Mol Psychiatry 13:631-640.

Woody N, Harrison Snyder N, Harris J (1969). Hyperprolinemia: Clinical and biochemical family study. Pediatrics 44:554-563.

Yamada KA, Tang C-M (1993). Benzothiadiazides inhibit rapid glutamate receptor desensitization and enhance glutamatergic synaptic currents. J Neurosci 13:3904-3915.

Yagi H, Furutani Y, Hamada H, Sasaki T, Asakawa S, Minoshima S et al (2003). Role of TBX1 in human del22q11.2 syndrome. Lancet 362:1366-1373.

Yakushiji T, Fakuda T, Oyama Y, Akaike N (1989). Effects of benzodiazepines and nonbenzodiazepine compounds on the GABA-induced response in frog isolated sensory neurons. Br J Pharmacol 98:735-740.

Zinkstok J, Schmitz N, Van Amelsvoort T, Moeton M, Baas F, Linszen D (2008).

Genetic Variation in COMT and PRODH is associated with brain anatomy in patients with schizophrenia. Genes Brain Behav 7:61-69. 


\section{VITA}

Adetutu Abiose Oyelami was born in Lagos, Nigeria, on November 9, 1980. She attended high school at Suleja (Federal) Academy, school for the gifted and talented, Niger State, Nigeria, in 1993 and graduated in 1998. She matriculated at Obafemi Awolowo University (OAU) in September 2000 and completed a Bachelor of Science degree in Microbiology in 2006. She joined the intergrated program in biomedical science at the University of Tennessee Health Science Center in August of 2007 and graduates with a Master's degree in Neuroscience in May 2010. 